\title{
HODNOTOVÁ NEUTRALITA, ANGAŽOVANOSŤ A VEREJNÁ ZODPOVEDNOSŤ SOCIOLÓGIE. SOCIOLOGICKÁ IMAGINÁCIA C. W. MILLSA V MEDIÁLNOM A POLITICKOM ZÁPASE O CHARAKTER SOCIOLÓGIE ${ }^{1}$
}

\author{
MIROSLAVTÍŽIK \\ Sociologický ústav Slovenskej akadémie vied \\ Katedra sociálnej práce, Pedagogická fakulta, Univerzita Komenského v Bratislave \\ E-mail:miroslav.tizik@savba.sk
}

\begin{abstract}
Value Neutrality, Engagement and Public Responsibility of Sociology. The Sociological Imagination by C. W. Mills in Media and Political Struggle for the Character of Sociology

C. W. Mills in his well-known The Sociological Imagination commented critically on the argument about value neutrality of sociology, even though he developed the heritage of value neutrality of a scientific analysis himself. However, in practice and in his The Sociological Imagination, he promoted engaged sociology. The seeming paradox is inspiring when it comes to reflecting on current sociology, which has been drawn into present struggles for the appearance of public space (mostly in media) and the character of politics in many ways. However, mass public mobilisation of middle-class and mostly more educated population in central Europe makes sociologists ask a question: which values and political visions are still acceptable and how shall they think about the engagement of sociology? Different historical, cultural and political conditions in central-European sociology also pose questions to again analyse Mills' definitions of value-neutral science and principles that a publically relevant and committed sociology should rely on. The Sociological Imagination by Mills has become a challenge for an updated and contextualized sociology of sociology.
\end{abstract}

Keywords: sociological imagination; sociology of sociology; value neutrality; surveys; engagement; mass media

„Nedovol, aby oficiálne formulácie verejných problémov alebo súkromné prežívanie osobných tažkostí ludí determinovali problémy, ktoré si zvolís za predmet svojho štúdia. Predovšetkým sa nevzdávaj svojej duchovnej a politickej nezávislosti tým, že by si sa nechal kýmkolvek nútit do neliberálnej praxe byrokratického étosu alebo liberálnej praxe morálnych povrchností." (C. Wright Mills, Sociologická imaginácia $)^{2}$

1 Príspevok vznikol v rámci riešenia grantových úloh VEGA 2/0046/19 a APVV-15-0653. Autor by rád podakoval anonymným recenzentom textu za podnetné komentáre a odporúčania.

2 V anglickom origináli Mills nepoužíval slovo practice, ale practicalities (Mills, 1959, s. 226), teda uvedený citát by sa mohol dat čítat, že nekritizuje prax byrokratického étosu a liberálnych morálnych povrchností, ale ich účelovost či praktickost', teda akoby šlo o kritiku hodnotovo a účelovo-racionálnych konaní, ako s nimi pracoval Max Weber. 
„Imaginárne je to, čo má tendenciu stat’ sa reálnym.“ (André Breton:

Le revolver à cheveux blancs) ${ }^{3}$

\section{Zabudnuté tradície sociológie}

Z pomerne bohatého a vplyvného diela Charlesa Wrighta Millsa sa do súčasnej sociológie ako jadro jeho odkazu zachováva najmä jeho práca Sociologická imaginácia, prvýkrát vydaná v roku 1959. Dôležitú úlohu v popularizácii Millsa ako autora termínu sociologická imaginácia a pri uchovaní mena autora i samotného konceptu v sociológii mali však pravdepodobne najmä učebnice. Medzi nimi má dôležité miesto globálne známa a prekladaná učebnica od Anthony Giddensa, ${ }^{4}$ ktorý samotný termín tvorivo čitatelom priblížil. Niektoré iné učebnice sa priamo opierajú o definície z Millsovej knihy (napríklad Lubelcová, 2017) alebo len bez komentára (Sopóci \& Búzik, 2019, s. 9) uvádzajú vybrané citáty (čím kanonizujú Millsa za klasika sociológie a autora definície sociológie), iné s termínom pracujú vel’mi vol’ne, či dokonca ho používajú v súvislosti s kritikou metodologických postupov v sociológii (Kubátová, 2006). V prípade Giddensa, no aj niektorých iných autorov slúži Millsovo slovné spojenie len ako odrazový mostík k rozvíjaniu vlastnej predstavy o sociologickej predstavivosti. Jeho ilustrácia sociologickej predstavivosti na „sociológii kávy“ (Giddens, 1999, s. 18) sa u mnohých vžila silnejšie ako pôvodné (a paradigmaticky inak zacielené) príklady z Millsovej emblematickej knihy a často sa stáva (napríklad u študentov na skúškach), že Giddensov príklad sociologickej predstavivosti je spätne pripisovaný autorovi termínu Millsovi. Kritiky velkej teórie (v podstate štruktúrneho funkcionalizmu T. Parsonsa) ${ }^{5}$ a abstraktného empiricizmu (teda práce so zložito rozvinutou metodológiou bez ukotvenia východísk výskumu v rámci nejakej širšej teoretickej perspektívy, spoločenskej či akademickej relevantnosti a historickom kontexte), teda len dve z jedenástich (ak zarátame aj dodatok) kapitol Sociologickej imaginácie sa stávajú druhom všeobecného poznania (no možno len sprostredkovaného). Tieto uchovávané dedičstvá knihy vytvárajú predstavu, akoby bola Sociologická imaginácia učebnicou ako sociologicky mysliet, ${ }^{6}$ teda ako sa stat dobrým sociológom. Učebnice sa stávajú filtrom smerujúcim naše čítanie $\mathrm{k}$ osvojeniu si postupov, ako prepájat teóriu a fakty, a tak sa vyhnút rizikám toho, čo Mills označil ako velkú teóriu a s ňou spojenú fetišizáciu pojmov a zároveň ako neuviaznut v metodologicky obmedzenom výskume fragmentu sociálnej reality vytrhnutého z jeho širších súvislostí.

S odstupom šest'desiatich rokov sa dá konštatovat', že rovnaké témy a rady, ako robit sociológiu lepšie a rigoróznejšie prináša väčšina základných učebníc sociológie vydaných po Millsovej Sociologickej imaginácii. Aj viaceré vymedzené ciele sociológie, napríklad snaha pochopit človeka v historickom kontexte sociálnej štruktúry, v ktorej sa nachádza,

\footnotetext{
"L'imaginaire est ce qui tend à devenir réel.“

V českom preklade Giddensovej učebnice od Jana Jařaba sa slovo imaginácia prekladá (a okrem odkazov na názov knihy alebo na Millsov koncept aj používa) ako predstavivost'. Podobne prekladali termín aj Klofáč s Tlustým v ich známej učebnici (Klofáč \& Tlustý, 1965).

Napríklad Kubátová (2006, s. 93-94).

6 Ako svoju učebnicu (svojím obsahom a úrovňou výkladu však určenú nie pre začiatočníkov) ju nazval Z. Bauman, ktorý $v$ istých ohladoch implicitne reprodukuje aj niektoré z Millsových predstáv o sociológii (Bauman, 1996).
} 
teda prostredníctvom jeho biografie situovanej k štruktúrach sociálneho sveta sa v rôznych prostrediach (biografická a humanistická perspektíva) stali súčastou všeobecného poznania a prístupu v sociológii a sú prítomné vo väčšine známych učebníc, dokonca aj politicky a hodnotovo odlišných autorov. Široko rešpektovaný multiparadigmálny charakter sociológie ako vednej disciplíny (Ritzer, 1975) nespochybňuje niektoré až učebnicové prvky v Millsovej koncepcii a nepolemizuje s ním.

Pri dnešnom čítaní Millsovej Sociologickej imaginácie a napríklad Bergerovho Pozvania do sociológie (Berger, 1991) akcentujúceho vel’mi podobným spôsobom humanistickú (ako sociologickú) perspektívu, či práce manželov Bergerovcov (Berger \& Berger, 1972) zdôrazňujúcej biografický prístup vidiet, že Mills bol v 60. rokoch len jedným z mnohých, hoci neprehliadnutelných autorov akcentujúcich takéto témy a optiku. Humanistickú perspektívu dodávali sociológii aj iní vtedajší autori, a to najmä tí, ktorí boli formovaní a ovplyvnení európskou tradíciou sociologického myslenia. ${ }^{7}$ Dilbar Alijevová podrobne popisuje celú plejádu na túto optiku nadväzujúcich autorov, ktorí od konca 60. rokov prispeli k rozvoju humanisticky zameranej sociológie. Tá sa stala protiváhou dovtedy vládnucemu scientisticko-pozitivistickému obrazu sociológie (Alijevová, 1985, s. 246). Vyzdvihla najmä Arthura MacClung Leeho, nadväzujúceho na Millsovskú tradíciu, autora knihy Sociológia - pre koho?, v ktorej volá po explicitnom prihlásení sa k hodnotám, s akými autor sociologické poznanie používa, čím sa okrem humanistického rozmeru sociológie presadzuje aj koncept hodnotových východísk skúmania. Niektoré témy načrtnuté u Millsa sú súčastou aj neskorších a už klasických úvodov do sociológie (Bauman, 1996). Sociologická imaginácia sa $\mathrm{z}$ tohto hladiska stáva akoby začiatkom druhej vlny globálneho vplyvu americkej sociológie. Zatial čo prvá vlna, ktorá bola zároveň druhou sociologickou generáciou v USA spojenou s profesionalizmom, scientizmom a empiricizmom, teda aj štandardizáciou výskumu, bola spojená s nástupom využívania kvantitatívnych metód typu survey a vytvorením objektivistickej a „hodnotovo neutrálnej“ výskumnej orientácie (Balon, 2011, s. 43-45; tiež aj Jeřábek, 2014), druhá okrem kritickej analýzy využívania kvantitatívnych metód v sebe dokázala integrovat jadro európskej a najmä nemeckej intelektuálnej a humanistickej tradície. $\mathrm{Z}$ tohto hladiska $\mathrm{v}$ súčasnosti už patrí Millsova Sociologická imaginácia skôr do dejín sociologického myslenia ako medzi aktuálne učebnice sociológie.

No Sociologická imaginácia nie je ani klasickou vedeckou monografiou, ani učebnicou a ani úvodom do sociológie (a ani tak nebola koncipovaná). Skôr je analýzou dobových problémov americkej sociológie v polovici 20. storočia a pokusom o vytvorenie jej nového programu ako súčasti integrovanejšej oblasti širšie definovaných spoločenských vied. Lubomír Sochor ju charakterizoval ako esej alebo sociologický pamflet, pričom zdôraznil historickú úlohu eseje ako autonómnej formy situovanej medzi filozofiu, vedu a literatúru pri rozvoji teoretického myslenia, ktorej úloha nie je systematizujúca, ale stimulujúca (Sochor, 1968, s. 198-199). Sochor však nevidel len špecifickú formu, ale upozornil aj na vtedy novátorské ambície knihy, ked’ ju charakterizoval ako „ojedinelý pokus o kritickú

7 Peter L. Berger, sám pôvodom z Európy, sa ako sociológ vyformoval práve v prostredí rozvíjajúcej tradície európskej sociológie (predovšetkým pod vplyvom nemeckej intelektuálnej emigrácie) na New School for Social Research (NSSR) v New Yorku, kde neskôr aj sám pôsobil. NSSR si dodnes kladie za jeden z cielov formovanie verejných intelektuálov (viac na https://www.newschool.edu/nssr/, navštívené 16. 9. 2020). Vplyv nemeckej sociologickej tradície je silne prítomný aj u C. W. Millsa. 
sebareflexiu sociológie, úvahu o poslaní sociológie v sociálnom živote, o jej rolách, cieloch a zmysle, pokus o založenie sociológie sociológie“ (Sochor, 1968, s. 193).

Kniha však nie je len sociologickou reflexiou dobovej americkej sociológie, ale má väčšie ambície. Zjavne využíva reflexiu aktuálneho stavu pre vytvorenie nového programu sociológie a sociálnych vied ako takých. Mills v knihe rozvíja niekol'ko základných línií, ktoré sa vzájomne prelínajú práve v snahe o definovanie dobovo relevantnej sociológie. Prvou líniou uvažovania je pokus o rehabilitáciu odkazu zakladatelov (najmä americkej) sociológie, kde medzi viacerými princípmi sociológie bol aj reformistický a emancipačný étos. Druhou líniou je analýza postavenia a základných výziev sociológie $\mathrm{v}$ čase prechodu medzi modernou a postmodernou spoločnostou, $\mathrm{v}$ čase nástupu nových podôb enormnej centralizácie moci a výrazne byrokratizovanejšej spoločnosti, čo kladie nové otázky na ujasnenie si vztahu otázok slobody, racionality a rozumu. ${ }^{8}$ Tretou dôležitou líniou uvažovania Millsa v Sociologickej imaginácii je vztah sociológie k iným spoločenským vedám a k dobovej verejnosti a verejným inštitúciám. ${ }^{9}$ Celou knihou sa však prelína jedna z Millsových klúčových a nadčasových tém, ktorou je problém hodnotovej neutrality sociológie a jej verejnej angažovanosti. Tak ako sa súčastou reflexie dobového „abstraktného empiricizmu“ stala otázka hodnotovej neutrality vedy, tak sa stala v jeho práci dôležitou otázka adekvátnej a spoločensky relevantnej verejnej angažovanosti sa sociológie. Ak kniha ako učebnica už nepatrí medzi aktuálne pomôcky a ak ju ani nemožno považovat' za druh úvodu do sociológie (príklady z knihy s odstupom polstoročia nemajú vel'kú didaktickú silu), zostáva velmi dobrou pomôckou pre uvažovanie nad aktuálnym stavom sociológie ako vedeckej disciplíny a jej miestom vo verejnom a politickom živote tej-ktorej spoločnosti. Millsova kniha je podla Howarda Beckera dôležitá práve z hladiska nutnosti kontextualizácie analýz na špecifické podmienky každej krajiny, aby bola relevantná vlastným problémom (Becker, 1994). Tak ako chcela byt Millsova sociológia relevantná problémom v USA, tak by mala byt’ sociológia robená v Brazílii relevantná problémom Brazílie a nie USA, Francúzsku alebo Nemecku, a tak možno povedat', že sociológia robená na Slovensku by mala byt’ relevantná problémom Slovenska.

8 Mills vo svojej knihe naznačil definíciu práve sa rodiacej postmodernej spoločnosti, za ktorej najvyhranejšie príklady považoval vtedajšie USA a ZSSR, a to práve s ohladom na spôsob fungovania mocenskej elity, médií a ekonomiky pri ovplyvňovaní a kontrole štruktúry spoločnosti a životov jednotlivcov v nich (Mills, 2008, s. 179, 195, 198).

9 Tomáš Kobes (2019, s. 148) konštatuje, že Mills sa v Sociologickej imaginácii obracia k sociálnej vede (ktorú uvádza rovnako ako Mills a aj prekladatel knihy do češtiny v jednotnom čísle) a vymedzuje úlohy sociologickej imaginácie vo vztahu k verejnosti. No cielom Millsových úvah nie sú len ludia z akademickej sféry, ale aj novinári, umelci, politici a podobne, teda širšia vzdelanejšia verejnost', do ktorej vkladal svoje angažované ambície. Otázne však je, či bolo skutočnou Millsovou ambíciou prezentovat verejnosti nový vedecký program (ako to naznačuje Kobes), alebo či chcel vzdelanejšej verejnosti ponúknut taký obraz sociológie, ktorý ju ukazuje v jej historických koreňoch, teda ako vedu fundamentálne sa prelínajúcu s inými vednými disciplínami. V knihe si kladie otázky o zmysle, úlohách a cieloch sociálnych vied a explicitne uvádza, že si kladie za ciel definovat” „význam sociálnych vied pre kultúrne úlohy našej doby“ (Mills, 2008, s. 23). Kobes však upozorňuje aj na další dôležitý rozmer Sociologickej imaginácie, ktorým je spoločenská zodpovednost' sociálnych vied (Kobes, 2019, s. 149). Možné posuny interpretácie Millsa, ktoré naznačujú, akoby chcel vytvárat novú zjednotenú vedu, môžu súvisiet aj s tým, že v angličtine sa ovela bežnejšie hovorí o social science $\mathrm{v}$ jednotnom čísle (a na mnohých miestach je to tak používané aj u Millsa), zatial čo európska a stredoeurópska tradícia používa dodnes bežnejšie označenie spoločenské vedy v plurále, čo implikuje ich vnútornú rôznorodost'. Pokus o vytvorenie novej podoby sociálnych vied sa tak môže lahko pretransformovat na pokus o vytvorenie novej jednotiacej sociálnej vedy. 
Práve táto málo pripomínaná línia Millsovho uvažovania môže byt zásadnou inšpiráciou pre analýzu súčasných podôb angažovanej alebo vo verejnom priestore prítomnej sociológie aj v strednej a východnej Európe. Práve tu existovala už na začiatku druhej polovice 20. storočia skúsenost's nastupujúcim moderným byrokratickým štátom a s jedným druhom angažovanosti, ktorá bola dokonca súčastou štátnej ideológie a programu rozvoja spoločenských a humanitných vied (a na jej problematickú podobu upozornil v Sociologickej imaginácii aj jej autor). A práve v tomto kultúrno-politickom a geografickom priestore sa začali po zmene režimov v roku 1989 podobné procesy, aké Mills identifikoval v americkej spoločnosti po druhej svetovej vojne - vytváranie nových foriem moci, nové podoby rastúcej byrokratizácie všetkých sfér života, odpútanie sa médií spod kontroly politických štruktúr a ich tesnejšie spojenie so svetom ekonomických záujmov, zmena fungovania verejných akademických prostredí, ich byrokratizácia a vstup do konkurenčných vztahov medzi sebou navzájom o zdroje a vplyv a mnohé iné spoločensko-ekonomické súvislosti, ktoré podporujú alebo stažujú presadzovanie demokratických princípov fungovania spoločnosti. V nových podmienkach sa v európskych krajinách bývalého socialistického tábora začala výraznejšie prejavovat aj verejná a politická angažovanost’ mnohých vedcov, či už priamo v straníckej politike, ${ }^{10}$ alebo vo sfére mimovládneho sektora, ktorí však v mnohých prípadoch vstupujú viac alebo menej otvorene do existujúcich straníckych zápasov o moc.

V prípade Slovenska, ako jedného príkladu zmeny podoby angažovanosti od takzvanej socialistickej angažovanej vedy až po dnešnú takzvanú občiansku angažovanost’ vedcov, sa verejná úloha sociológie a spoločenských vied ukazuje ako zásadná. A to z viacerých hladísk. Jedným je obraz a odkaz sociológie v médiách, druhým existencia rôznych verejných iniciatív, ktoré sú aspoň verbálne propagované alebo legitimizované aj mnohými sociológmi. V rokoch 2018 a 2019 bola jednou z takýchto najviditelnejších iniciatíva Za slušné Slovensko, ${ }^{11}$ ktorá mobilizovala čast’ verejnosti pri tlaku na riešenie viacerých politických a spoločenských problémov. Masová verejná mobilizácia strednej a najmä vzdelanejšej časti populácie, ktorú verejne podporujú aj viaceré osoby intelektuálneho života a sociológie, kladú pred spoločenských vedcov také otázky ako napríklad: Aké hodnoty a politické vízie sú ešte prijatelné pre zachovanie si profesionálnej identity sociológa a verejnej zodpovednosti odboru? V čí prospech a v čí neprospech sa sociológia verejne angažuje? Sú a majú byt’ prezentácie práce sociológov vo verejných médiách hodnotovo neutrálne? Takisto využívanie argumentu o sociologických metódach ako hodnotovo a ideologicky neutrálnych a prinášajúcich nestranné a objektívne fakty pri interpretovaní výsledkov výskumu, ktoré bolo a je častým zdôvodnením nestrannosti sociológov v oboch politických režimoch, nanovo kladie otázky o charaktere a poslaní

10 Minimálne dvaja z kandidátov na funkciu prezidenta Slovenskej republiky otvorene deklarovali svoju sociologickú expertnosṫ ako výhodu pre výkon politickej funkcie, viacerí to zasa využívali v politických funkciách či už ako poslanci parlamentu, alebo členovia vlády. Po roku 1990 vzniklo viacero nadácií a mimovládnych organizácií s viacerými sociológmi vo vedení, ktoré sa otvorene zapájali do straníckeho politického zápasu pri presadzovaní rôznych zákonov, princípov alebo pri mobilizácii voličov vo volbách. Viacerí sociológovia z mimovládneho sektora prešli do aktívnej straníckej politiky, prípadne po odchode z politiky pokračovali v práci $\mathrm{v}$ mimovládnom sektore. O prezentáciách sociológov v prezidentských kampaniach viac napríklad v Kusá (2005).

11 Za slušné Slovensko má oficiálnu stránku dostupnú na https://zaslusneslovensko.sk/ (navštívené 16. 9. 2020). Okrem jazyka, ktorý používa samotná iniciatíva (aj svojím názvom), je pre analýzu dôležité aj to, ako bola a je iniciatíva propagovaná v médiách. 
spoločenských vied v demokratickom svete, teda v podstate rovnaké otázky, aké si kládol C. W. Mills pred viac ako polstoročím. Tieto otázky však, na rozdiel od Millsovej knihy, sú dnes v globálnej sociológii ovela živšie a diskutovanejšie, stávajú sa (aj s explicitnými odkazmi na verejnú úlohu sociológie pri rozvíjaní blaha spoločností a ochrany jednotlivcov a skupín, ktoré sú predmetom výskumu) súčastou etických kódexov profesijných združení sociológov (Code of Ehics ISA, 2001) a vytvárajú prirodzené prepojenie až k súčasným prístupom, ktoré sú označované ako sociológia sociológie (Bourdieu \& Wacquant, 1992; King, 2007; Halsey, 2004), verejná sociológia (Burawoy, 2005) alebo angažovaná sociológia (Habermas, 2013). V prostredí slovenskej (ale nielen) sociológie vzniká otázka, či sociológia vôbec reflektuje svoje vlastné hodnotové pozadie, či chráni záujmy tých jednotlivcov a skupín, ktoré skúma, alebo tiež či je autonómna pri svojej misii angažovanej alebo hodnotovo neutrálnej vedy vo vztahu k širšej verejnosti. Reflexia odkazu C. W. Millsa ako jedného z priekopníkov sociológie sociológie a jeho aktualizácia v slovenskom prostredí môžu poukázat’ na podobnosti, prípadne rozdiely existujúce v odlišnom historickom, ale aj spoločensko-politickom kontexte.

\section{Angažovanost' ako návrat ku koreňom sociológie}

V slovenskej sociológii mala Millsova Sociologická imaginácia odozvu už v 60. rokoch, najmä po jej preklade do češtiny v roku 1968. Na význam knihy pre angažovanú sociológiu upozornil napríklad vtedajší najvplyvnejší predstavitel' oficiálnej, teda marxisticko-leninskej podoby sociológie Andrej Sirácky. V úvahe o Millsovej sociológii sa sústredil hlavne na rozbor Millsovej angažovanej sociológie, najmä v súvislosti s podla neho chýbajúcimi pokusmi o „marxistickú analýzu štrukturálno-funkcionálnych a iných sociologických teórií a ich dôsledkov pre naše sociologické myslenie i pre našu spoločensko-politickú prax“ (Sirácky, 1971, s. 16). Sirácky ju analyzoval na pozadí vlastnej predstavy o marxistickej sociológii ako o „progresívne angažovanej“ (tamže), čím zjavne pripúštal aj iné formy angažovanosti. Ked’ hovoril o marxistickej sociológii (zahŕňajúcej aj odkazy na Lenina), konkrétne o nej hovorí ako o plniacej funkciu triednej, politickej aj ideologickej (socialistickej) angažovanosti. V Siráckeho článku bolo cítit čiastočne obavy o podobu dobovej sociológie, ktorá bola podla neho zaplavená empirickými štúdiami ovplyvnenými práve dobovým americkým štruktúrnym funkcionalizmom. A práve pred takýmto výkladom Millsa sa pokúsil varovat’ v doslove k jeho českému prekladu Sochor. Upozorňoval na dva druhy reakcií na Millsovu knihu v Československu - na jednej strane boli tí, čo v nej videli plodný zdroj k tomu, aby domáca sociológia včas reflektovala svoju spoločenskú úlohu a svoje úlohy a aby sa nestala tým, čím bola vtedajšia americká sociológia. Podla druhého názoru Mills mohol posilnit konzervatívny, odmietavý postoj k empirickej sociológii, ktorý bol predtým dosṫ silný a nebol úplne prekonaný (Sochor, 1968, s. 194). Siráckeho prístup k Millsovi aj dobovej sociológii v sebe kombinoval oba tieto postoje.

$\mathrm{V}$ českom a slovenskom prostredí sa však objavili ešte aj iné prístupy $\mathrm{k}$ hodnoteniu Millsovho diela. Príkladom môže byt' Kobes, ktorý dost’ neobvykle interpretoval Millsov program sociológie a aj jeho Sociologickej imaginácie. Millsov program prezentuje ako druh misionárskej aktivity a sociológov propagujúcich projekt osvietenstva stavia 
do pozície, že svoj ideál nadrad’ujú „nad reálne problémy obyčajných ludí a pasujú sa tak do úlohy ich hovorcov“. Millsovi vyčíta, že jedinečnost’ obyčajných ludí, ktorá by mala byt vysvetlená, je prehliadaná a je „výrazom priemeru čohokolvek“ (Kobes, 2019, s. 158). V podstate odhliadol od iných častí jeho programu a pripísal Millsovi rovnakú výčitku, akú Mills pripisoval dobovej liberálnej moralistickej sociológii, ktorú kritizoval (Mills, 2008, s. 98). K takémuto záveru mohli Kobesa okrem iného doviest' humanistické a otvorene osvetové (oslobodzujúce, teda v istom ohlade misionárske) ambície Millsa, ktoré $\mathrm{v}$ knihe spája s verejným pôsobením sociológie a sociálnych vied. Práve takéto zhodnocovania Sociologickej imaginácie a Millsovho diela ako celku vyžadujú ozrejmenie a dôkladnejšie vysvetlenie práve tej časti Millsovej práce, kde nepanuje v interpretácii kanonizovaná zhoda, ale kde dochádza k rôznosti a až protichodnosti výkladov jeho myšlienok. V týchto situáciách je totiž jediným legitímnym prístupom rozbor Millsovho pôvodného diela.

Mills sa v podstate vracia ku koreňom sociálnych vied v Spojených štátoch, ktoré boli v 19. storočí úzko spojené s reformnými hnutiami a ukazuje na ich ambície „aplikovat’ vedu“ na spoločenské problémy bez výslovných politických ambícií. Ich ambície charakterizoval ako pokus hnutia premenit problémy nižších vrstiev aj na problémy stredných vrstiev. Toto hnutie však podla Millsa postupne prestalo byt' nositelom radikálne reformnej ideológie (hodnôt) dobových stredných vrstiev, čo oslabilo a presunulo dôraz zo zlepšovania hmotných životných podmienok na obmedzený záujem o sociálnu prácu, rôzne dobročinné organizácie, starostlivost’ o deti a reformu systému väzenstva (Mills, 2008, s. 94). Postupne sa raná reformná sociológia stredných vrstiev, ktorú spája s liberalizmom rozpadla do rôznych akademických disciplín a na rôzne podoby inštitucionalizovanej verejnoprospešnej činnosti, čo však neznamená, že by sa tieto stali morálne neutrálnymi a vedecky sterilnými (tamže). V sledovanom historickom exkurze naznačuje dve rôzne podoby angažovanosti - pôvodnú radikálnejšiu, postupne sa meniacu na druhú - liberálno-reformistickú. Obe však spája s rovnakými koreňmi. Práve pri reflexii koreňov a aj zmene v angažovanosti sa sociálnych vedcov Mills ukazuje na ideové pozadie spojené s dobovými hodnotami a presvedčeniami stredných tried, spojených s liberalizmom, opierajúcim sa o (aj ekonomické) myšlienky rovnováhy. Tu možno vidiet aj zdroj kritickosti Millsovho prístupu k jeho súčasníkom. Liberálne idey, naviazané na predstavy rovnováhy, sociológov postupne ovplyvnili aj v tom, že mali skon sústredit’ sa na jeden vybraný detail, teda rozptylovat’ svoju pozornost’ a považovat všetky fakty za rovnocenné. A práve toto ideové pozadie považuje za problém dedičstva americkej sociológie, ktoré formovalo fungovanie vedy aj v polovici 20 . storočia. Z ideológie stredných tried podla Millsa sociológovia vytvorili druh „pluralitnej kauzality“, teda že každý sociálny jav vyplýva z množstva malých príčin, čo vyhovuje liberálnej politike „postupných reforiem“ a čo sa prenieslo aj do štýlu sociálneho bádania (Mills, 2008, s. 95). Nutnost’ skúmat’ vždy len jednu situáciu v jednom okamihu vo svojich dôsledkoch stažuje možnost' pochopit štruktúru existujúceho status quo. Okrem toho jazyk dobovej sociológie, využívajúci vel’a fráz, znižuje možnost’ chápat', čo vlastne je moderná sociálna štruktúra (Mills, 2008, s. 96). Táto liberálna účelnost' (prax) $)^{12}$ sa posilnila aj kvôli fragmentárnej

12 V pôvodnej anglickej verzii knihy používal Mills slovo practicality, teda účelnost̉ alebo praktickost (Mills, 1959, s. 86). Aj na dalších miestach bude v zátvorke uvádzané, kde český preklad používa slovo prax. Na viacerých miestach tohto textu, kde je citovaný český preklad upravený alebo doplnený z pôvodného vydania $v$ angličtine, sú uvedené odkazy na oba zdroje. 
štruktúre amerického akademického prostredia, kde sa nielen univerzity, ale aj disciplíny začali voči sebe vymedzovat', a teda aj uzatvárat’ sa do svojich vlastných prostredí. ${ }^{13}$ Okrem toho Mills zdôrazňuje, že popisovaná liberálna účelnost’ (prax) má tendenciu smerovat’ $\mathrm{k}$ apolitickosti alebo $\mathrm{k}$ akémusi druhu demokratického oportunizmu (Mills, 2008, s. 97). Takáto účelnost' (prax) vyhovuje lud’om, ktorí sa z moci svojho spoločenského postavenia zaoberajú - väčšinou z pozície autority - sériami individuálnych prípadov. Liberálna účelnost' (prax) je moralizujúcou sociológiou prostredia (Mills, 1959, s. 88; Mills, 2008, s. 98), v ktorom výskumníci pôsobia. ${ }^{14}$ Mills zhŕňa tento problém liberálnej účelnosti (praxe) v sociológii v tom, ako uplatňuje hodnotenie toho, čo je a čo nie je „problém“. Liberálna účelnost’ za „problém“ považuje všetko čo: 1. sa odchyluje od spôsobu života stredných vrstiev a v malých mestách, 2. nie je v súlade s provinčnými (rurálnymi) zásadami stability a poriadku, 3. nie je v súlade s optimistickými pokrokárskymi heslami „kultúrnej medzery“, 4. sa neprispôsobuje primeranému sociálnemu pokroku, 5. sa vyjadruje v pojme „prispôsobenia“ („prispôsobivosti“) a v opaku „zlého prispôsobenia“ („neprispôsobivosti“). Spája ju s propagáciou konformity a s normami a rysmi, ktoré sa obvykle spájajú s malomestskými strednými triedami (Mills, 1959, s. 90; Mills, 2008, s. 100). Pri práci s týmto dobovým vymedzením však treba byt', vzhladom na viac ako polstoročný odstup a iný kultúrno-spoločenský priestor, opatrný. Uvedené vlastnosti stredných tried nemožno reprodukovat mechanicky, pretože v stredoeurópskom priestore sa hodnoty stredných tried odlišujú, nie sú tak výrazne spojené s rurálnym prostredím, ako v originálnom vydaní konštatoval Mills. Dnes viac akcentujú to, čo propagoval aj Mills - potrebu sebavyjadrenia, ochranárstvo voči vybraným sociálnym skupinám a podobne. Z toho, čo Mills charakterizoval ako problém vedy, je však stále nutné reflektovat', ako sa do vedeckej praxe odzrkadlujú hodnoty a predstavy tried, v ktorých pôsobia alebo z ktorých pochádzajú akademickí pracovníci.

Jadrom Millsovej práce však nie je kritika liberálnej, teda limitovanej podoby angažovanosti, ale kritika rezignácie na akúkolvek formu otvorenej verejnej angažovanosti, čo sa spájalo s deklarovaným nehodnotiacim charakterom sociologického výskumu. Oproti skôr popísanej podobe istým spôsobom stále verejne angažovanej liberálnej účelovosti (praxe) Mills postavil novú neliberálnu účelovosṫ (prax) sociológie (alebo spoločenských vied všeobecne). To, čo označil ako neliberálny prístup podla neho nemá reformné ambície verejnej angažovanosti pri intervenciách do sociálneho sveta, ale slúži cielom vel'kých inštitúcií (politickým stranám, korporáciám, priemyslu, armáde a podobne) (Mills, 2008, s. 102). Toto vedie aj k zmene záujmu vedeckého výskumu, ktorý presúva svoju pozornost’ od utrápených ludských bytostí na dne spoločnosti, od ludí nekonvenčného správania, zanedbaných žien, migrujúcich sezónnych robotníkov či pristahovalcov a podobne $\mathrm{k}$ najvyšším vrstvám spoločnosti - k jej elite (Mills, 2008, s. 106). Mení sa tak aj verejnost', pre ktorú pracujú. Táto nová skupina, ktorá sa stáva zdrojom možností, ale aj cielom výskumu, sa však už neviaže na žiadnu explicitnú ideológiu. Jej hodnotový svet nie je ukotvovaný ideologicky, ale vo vztahu k praktickým záujmom prostredia, v ktorom

13 Bourdieu neskôr tieto témy fragmentarizácie, vzájomných konkurenčných zápasov a vytváraní novej podoby vedy charakterizoval na príkladoch zmeny francúzskeho akademického prostredia vo viacerých prácach, napríklad Homo Academicus alebo La noblesse d'État (Bourdieu, 1984, 1989).

14 Mills ako jeden $\mathrm{z}$ príkladov takejto praxe uvádza odkazy mnohých sociológov na teóriu kultúrnej medzery, čo sa $\mathrm{v}$ súčasnosti $\mathrm{v}$ stredoeurópskom akademickom prostredí prejavuje $\mathrm{v}$ teórii zaostávania, dobiehania a podobne (viac napríklad v Búzik, 2016). 
žije, je to druh mentality podnikatela. Mills však upozorňuje aj na pretrvávajúci mocenský rozmer profesionalistického a zdanlivo nehodnotiaceho prístupu. Ako to interpretoval Balon, pozitivistická ortodoxia si chcela vedcov naklonit’ tým, že na nich delegovala špecifické prednosti, nedostupné bežnému človeku. Argumentácia profesionála je oproti bežnej nekontrolovanej argumentácii logická a koherentná a tým dáva role profesionála privilegované postavenie. Spolu s nezaujatým skúmaním dáva vedcom masku neutrality, ktorá vedcovi umožňuje, v prípade, že je konformný so štandardizovanými požiadavkami svojej roly, nespochybnitel’ný a nenapadnutelný status. Neutralita sa stala púhou maskou, za ktorou sa skrývajú rôzne záujmy a ambície (Balon, 2002, s. 8). Mills vo svojej analýze popisuje prechod od reformátorskej sociológie zameranej na problémy nižších vrstiev cez moralistickú liberálnu sociológiu reprodukujúcu morálny svet stredných tried k neliberálnej službe elitám. Sochor upozornil práve na túto Millsovu v podstate ideologickú analýzu, v ktorej jej autor dospel k záveru, že aj také prúdy sociologického bádania ako Parsonsova „vellká teória“ alebo jej náprotivok, teda radikálny „abstraktný empiricizmus“, t. j. (ideálnotypické) prúdy, ktoré sú subjektívne krajne protiideologické, pretože chcú stát len na pôde rýdzej vedy a odmietajú všetky nevedecké a mimovedecké ciele, sa menia v sociálnom kontexte na ideológiu v klasickom význame slova, teda na falošné vedomie - na klam a sebaklam (Sochor, 1968, s. 194). V súčasnejšej terminológii, napríklad v kontexte teórie P. Bourdieua, by sa dalo hovorit', že medzi vedcami praktizujúcimi takéto vedecké prístupy sa prejavuje illusio, ktoré sa stáva princípom kolektívnej činnosti v konkrétnych skupinách vedcov. Byrokratický étos, ktorý Mills ilustruje práve na praxi abstraktného empiricizmu, považuje za druh neliberálnej účelnosti (praxe). Tá prináša do sveta sociálnych vied štandardizáciu, rutinizáciu, výberovost’, typizovanie ludí a výskumy, ktoré v takej miere ako dosahujú vytýčené praktické ciele, pomáhajú zvyšovat účinnost’ a autoritu a tým aj prevahu byrokratických foriem ovládania $\mathrm{v}$ modernej spoločnosti (Mills, 2008, s. 112).

Rozlišovanie prežívajúcej praktickej a istým spôsobom angažovanej vedy, pôsobiacej v rámci morálnych hodnôt stredných tried, a na druhej strane stále silnejúcej neliberálnej účelnosti v sociologickom výskume, kde byrokraticky organizovaná prax výskumu slúži k dosahovaniu praktických ciel’ov zadávatelov výskumu, je klúčové aj pri reflexii úlohy sociológie a spoločenských vied vo verejnom svete. Naznačuje to minimálne dva odlišné princípy, ktoré vládnu (bourdieuvsky povedané - sú doxou) v rôznych akademických prostrediach. Bud' väčšiu alebo menšiu otvorenú reformistickú angažovanost', zdôvodňovanú viac či menej aj hodnotovo, alebo programovú nestrannost', zakrývajúcu praktické ciele vedeckých výskumov. Obzvlášt aktuálne to je v súčasnosti, ked’ sa pôvodné autonómne rámce národných štátov výraznejšie oslabujú v prospech nadnárodných vplyvov, čo má dôsledky aj na možnosti a mieru autonómie „národných“ akademických spoločenstiev i iných verejných aktérov. Zatial’ čo Mills pri úvahách o misijnej úlohe oslobodzujúcej sociológie vkladal nádeje do novinárov (konkrétne sa obracal na novinárov vo vtedajších Spojených štátoch), súčasná prax vlastníctva médií vel'kými globálnymi korporáciami a vydavatel’skými domami výrazne mení možnosti jednotlivých aktérov vo sfére novinárskych profesií, obzvlášt v malých štátoch strednej a východnej Európy, kde je ovela menší mediálny trh s menšími možnostami konkurencie voči silným globálnym aktérom. Okrem toho, aj tie médiá, ktoré sú vlastnené a spravované domácimi vlastníkmi a správcami sú vystavené pravidlám, ktoré spoluurčujú ekonomicky 
silnejší hráči na mediálnom trhu. Tieto súvislosti je dôležité zohladňovat pri pokusoch prenášat Millsove idey do kontextu súčasných spoločností, napríklad aj v stredoeurópskom priestore.

\section{Verejnost' a verejná mienka}

Ak by súčasný čitatel' Sociologickej imaginácie na Slovensku (alebo asi aj v celej strednej Európe, ktorá zakúsila obdobie štátneho socializmu) chcel naznačit', v čom je dnes kniha stále relevantná, musel by vypustit’ známu kapitolu o vel'kej teórii. Alebo by musel nahradit popis problémov vel'kej teórie T. Parsonsa popisom problémov spojených s dominantným marxisticko-leninským charakterom sociológie v období pred rokom 1989, aby pochopil tažkosti mnohých dobových kriticky zameraných sociológov, a to nie len z hladiska povahy vtedajšej teórie, ale aj jej jazyka. Práve kritika neduhov dominantného typu sociológie bola tým, čo bolo pre mnohých čitatelov na Millsovej knihe prítažlivé pred rokom 1989. Ťažšie by sa hladali tieto paralely v neskoršom období, spojenom s akceptovaním sociológie ako multiparadigmálnej vedy a pri zavedení pluralitného modelu fungovania akademických inštitúcií. Aj ked’ reálna situácia v pluralite a multiparadigmalite sociológie nie je nespochybnitel’ne všeobecne prijímaná, nedá sa hovorit, že by nejaká teória bola dominantná, a to aj z toho dôvodu, že teória ako taká sa dostala vo vel'kom množstve výskumov do úzadia a je v sociológii skôr mimo záujmu hlavného prúdu sociológov.

O to väčšiu satisfakciu môže čitatel pocítit pri čítaní kapitoly o abstraktnom empiricizme. Táto kapitola môže byt’ východiskom kritického uvažovania aj o súčasnej podobe mediálnej (teda verejnej) prezentácie sociológie a výsledkov sociologických výskumov. Práve ludia z médií, vedci, umelci a ich obecenstvo, vydavatelia a celkovo vzdelanejšia čast’ populácie bola cielovou skupinou, na ktorú Mills zameral svoju knihu a práve u nich chcel podporovat rozvoj sociologickej imaginácie ako kvality uvažovania. ${ }^{15} \mathrm{~V}$ tejto súvislosti treba zdôraznit', že Millsova kniha je postavená na normatívnych, t. j. silných hodnotových základoch, ktoré však explicitne priznáva.

Mills v súvislosti s (dobovou americkou) verejnostou v podstate hovorí o jej dvoch podobách, pričom jednu, tú širšiu, spája s rizikom premeny na masu, do druhej zaraduje uvedené skupiny vzdelanejších a spoločensky vplyvnejších ludí, ktoré by sa dali stotožnit’ s tým, čo býva v súčasnosti označované ako kognitívna trieda. Jeho jazyk pri rozlišovaní týchto tried je však otvorene normatívny, čo znižuje možnosti jednoznačne operacionalizovat', kto je vlastne súčastou, tej-ktorej verejnosti. Ked’ používa vágne definície o vôli a schopnosti mysliet’ a pracovat’ na sebe (čo sa dnes nazýva schopnost’ kritického myslenia) a o určitom angažovaní sa pri objasňovaní problémov sveta, nedá sa lahko identifikovat', kto vlastne tieto znaky naplńa a koho by sme teda mohli považovat' za perspektívny objekt jeho snahy. Normativita je prítomná aj v jeho slovníku, ked' hovorí o pravej a nepravej verejnosti. Tá čast' verejnosti, ktorú spája s nádejou na zmenu a oslobodzovanie človeka sa podla Millsa prejavuje myslením, teda schopnostou polemizovat’ sám so sebou alebo debatovat’ s druhými. Takýto človek je druhom vychovávatela, ktorý

15 Quality of mind, čo bolo v češtine preložené ako duševná schopnost'. 
sa musí snažit rozvíjat mužov a ženy, ktorí môžu a sami chcú pokračovat’ v tom, čo vychovávatel' alebo učitel' (educator) začal: konečným produktom oslobodzujúcej ${ }^{16}$ výchovy sú jednoducho muži a ženy snažiaci sa o sebavzdelávanie, o sebazdokonalovanie, skrátka slobodní a rozumní jednotlivci. Spoločnost', v ktorej prevládajú takíto jednotlivci, je demokratická v jednom z hlavných zmyslov tohto slova (Mills, 2008, s. 202). Predpokladom demokratickej spoločnosti je pravá verejnost', v ktorej si jej uvedomelý (knowledgeable) príslušník uvedomuje a pocituje, že to, čo považuje za svoje osobné problémy, sú vel'mi často aj problémy ostatných ludí, a čo je dôležitejšie - chápe, že ich riešenie nie je v moci jednotlivcov, ale že je možné iba zmenou štruktúry skupiny, v ktorej žije a niekedy zmenou štruktúry celej spoločnosti (Mills, 2008, s. 203). Na druhej strane podla neho existuje masa, no ako upozorňuje Sochor, Mills nechápal masu tak, ako bola chápaná v marxistickom výklade, ale považoval ju za číry konglomerát atomizovaných jednotlivcov, ktorí nie sú spätí väzbami triedneho záujmu a solidarity. Je to „osamelý dav“, zhluk ludských atómov. Termín masa má teda význam ako pól dichotómie, ktorej druhým pólom je mocenská elita. Masa je nemohúca, personifikáciou moci je elita (Sochor, 1968, s. 207). Ludia masovej spoločnosti, teda príslušníci nepravej verejnosti majú svoje starosti, ale obvykle si neuvedomujú ich význam a zdroj (Mills, 2008, s. 203). Tento vo svojej podstate normatívny projekt ideálnej demokracie však tým, že kladie dôraz na mieru rozšírenosti istého typu ludí v spoločnosti, odhliada práve od inštitúcií a zvyklostí, a teda aj od samotných štruktúrnych podmienok v existujúcich spoločnostiach. Práve toto je jednou $\mathrm{z}$ argumentačne slabších častí Millsovej Sociologickej imaginácie.

Nejasná zostáva pozícia dobovej intelektuálnej časti americkej spoločnosti, pracujúcej v oblasti informácií, kultúry a novín. Do nich vkladá Mills nádeje, akoby boli nositelmi vlastností a možností starších radikálnych reformistických skupín. Nádej vkladal do kritikov sveta dobovej intelektuálnej triedy, kam zaradoval aj sociológov stredného prúdu. Táto skupina intelektuálne pracujúcich bola vtedy zjavne na pomedzí svetov novej a starej verejnosti, ale aj na pomedzí sveta elity a masy. Zameranie pozornosti na túto medznú skupinu v súčasnom stredoeurópskom prostredí, konkrétnejšie na Slovensku môže byṫ testom využitel’nosti jeho prístupu a aktuálnosti jeho záverov. Práve prostredie kognitívnej časti verejnosti, spojené so svetom médií alebo svetom, v ktorom sa informácie spracovávajú a interpretujú pre širšiu verejnost', je tým prostredím, kde sa dnes verejne najaktívnejšie pracuje s výsledkami sociologických výskumov a pri verejnej mobilizácii k zmene existujúcich pomerov v spoločnosti. No príklady zo Slovenska by s velkou pravdepodobnostou neobstáli v porovnaní s predstavou, ako verejnú demokratizačnú úlohu týchto skupín videl Mills. Súčasná mediálna prax narábania so sociológiou by sa skôr mohla stat' cielom kritiky v podobnom duchu a s podobnými argumentmi, aké využíval na kritiku politicky demobilizovanej časti verejnosti v 50 . rokoch v USA. Sociologickou imagináciou totiž označoval schopnost’ tých, čo pracujú (vo veku faktov) s faktmi (novinárov, vzdelancov, umelcov, vedcov a vydavatelov)

16 Oslobodzujúca výchova - liberation education. V českom preklade sa pomerne volne narába so slovom education, ktoré je prekladané ako výchova, teda nie vzdelávanie, čo naznačuje akoby tá strana verejnosti, ktorá nie je dostatočne uvedomelá, mala byt vychovávaná tak, ako sú vychovávané deti dospelými. Podobne slová liberal a liberating sú niekedy prekladané ako oslobodzujúce, inokedy ako liberálne. Podla kontextu raz slovo oslobodzujúce (liberating) vychádza ako želané, inokedy je slovo liberal označením politickej ideológie americkej strednej triedy (Mills, 1959). 
správne využívat informácie a rozvinút svoj intelekt ${ }^{17}$ tak, aby získali celkový obraz o tom, čo sa deje vo svete a k čomu môže dôjst’ u nich samých (Mills, 2008, s. 9). Od roku 1990 sú tieto skupiny výrazne prítomné vo verejnom priestore aj na Slovensku a pri vytváraní a výbere faktov, a tým pádom aj pri formovaní verejnej mienky bez toho, aby boli priamo podriadené oficiálnej moci. Otázkou však zostáva, či dnes vo svojej práci využívajú millsovsky chápanú sociologickú imagináciu. Normatívny predpoklad konkrétnej verejnej úlohy takejto skupiny ludí u Millsa je v súlade s jeho normatívnou predstavou o cieloch sociologického bádania. Oboje by malo smerovat k pochopeniu širšej historickej scény a sociálnej štruktúry v jej význame pre vnútorný život a pre vonkajšiu životnú dráhu rôznych jednotlivcov a k pochopeniu, ako jednotlivci v spleti svojich každodenných skúseností získavajú často falošné vedomie o svojom spoločenskom postavení. Práve pri odkrývaní štruktúr moderných spoločností sa môže pocit stiesnenosti jednotlivcov zmenit’ na účast’ na veciach verejných (Mills, 2008, s. 9). Táto Millsova profesionálna ambícia a definícia sociologickej imaginácie ukazuje na jeho silnú väzbu na nemeckú intelektuálnu tradíciu, spojenú so zacielením sociologického bádania na jednotlivca a obsahujúcu aj emancipačný étos oslobodzovania jednotlivca (ktorému chce pomôct’ uniknút zo sveta kolektívnych predstáv k individuálnemu aktívnemu sebauvedomeniu). Takýmto uvažovaním nad termínom predstavivost' (imaginácia) sa odlišuje od druhej vplyvnej línie, ktorou je francúzska tradícia, dodnes výraznejšie spájajúca imagináciu so zdrojmi významov a motívov konania pre jednotlivcov a pre pochopenie kolektívnych akcií. ${ }^{18}$

Millsovské emancipačné a sociálno-kritické ambície a ani jeho sociologická imaginácia ako druh sebareflexie sociológie nie sú vo verejných debatách na Slovensku naplñané. Vidiet to na dvoch príkladoch prítomnosti sociológie vo verejných debatách - pri vystupovaní sociológov a pri prezentácií výskumov, ktoré sú označované ako sociologické, hoci nie vždy sú výsledkom práce sociológov alebo sociologických pracovísk. Pri podrobnejšom pohlade na spôsob práce s výsledkami najmä kvantitatívnych výskumov sa ukazuje skôr podobnost's tou sociológiou, ktorú Mills kritizoval.

V súčasnosti sa pri práci s výsledkami rôznych empirických (teda kvantitatívnych) výskumov stáva vel’mi častou stratégiou médií, rovnako ako aj viacerých sociológov to, čo sa využíva v marketingu - vytváranie person, teda akýchsi typov l’udí, do ktorých si môžu potenciálni konzumenti z rôznych cielových skupín projektovat’ svoje pozitívne alebo negatívne predstavy. ${ }^{19}$ Sociologické analýzy a ich mediálne prezentácie sa velmi často uchylujú k dichotomickému kategorizovaniu ludí, na čo sa využívajú zdanlivo neutrálne

17 V angličtine použil Mills slovo reason (Mills, 1959, s. 5), čo bolo do češtiny preložené ako duševná schopnost'.

18 Analýzy kolektívnych predstáv alebo reprezentácií sú základom sociologickej tradície už u Durkheima. Hoci sú súčasné koncepcie Michela Maffesoliho a Pierra Bourdieuho v podstate až paradigmaticky odlišné, spája ich sústredenie sa na analýzy istého druhu neutrálnejšie chápanej nevedomosti jednotlivca v sociálnom živote, ako je Millsovská (či Marxova) predstava falošného vedomia. Bourdieu to operacionalizoval termínom habitus, Maffesoli, opierajúc sa o durkheimovskú tradíciu, to spája s analýzami kolektívnej alebo sociálnej imaginácie, ktorá umožňuje uskutočnenie celistvej osobnosti človeka ako sociálnej bytosti (napr. Maffesoli, 1993).

19 Zatial čo v komerčnom marketingu ide najmä o vytváranie pozitívnych (humanizujúcich) obrazov (súčasná legislatíva silne reguluje vymedzovanie sa značiek a produktov v negatívnom duchu voči konkurencii), v politickom marketingu sú vytvárané pozitívne (humanizujúce), ale aj negatívne (dehumanizujúce) persony. 
sociálnodemografické kategórie ${ }^{20}$, prípadne si za svoju intelektuálnu a verejnú ambíciu dávajú pozitívnym prezentovaním voličov (a negatívnym vykreslovaním nevoličov) pomáhat pri zvyšovaní volebnej účasti v rôznych typoch volieb. Robia teda to, čo Mills vystavil kritike vo svojej reflexii abstraktného empiricizmu a čo kritizoval na dobovej sociológii, ked' sa spojila s neliberálnou účelnostou manažerizmu, typického napríklad pre školu ludských vztahov (human relations) v priemysle. Táto línia využívania výskumu pracuje pri charakterizovaní l’udí s dichotomickými kategóriami, napríklad inteligentný - neinteligentný, racionálny - neracionálny, spokojný - nespokojný a podobne (Mills, 2008, s. 102). Skromné výsledky výskumov politického správania podla neho zodpovedali úrovni prepracovania metód a vynaloženej starostlivosti, pričom konštatoval, že často ide o výsledky rozsiahlych volebných výskumov bez toho, aby sa čo len slovom zmienili o straníckych mašinériách, slúžiacich k „získavaniu hlasov“, alebo o nejakej politickej inštitúcii (Mills, 2008, s. 60). Prax prezentácie sociológie v médiách akoby aj na Slovensku zodpovedala dobovej sociológii v USA, ktorá „usilovne slúžila komerčným záujmom masmédií a reklamného priemyslu“ (Mills, 2008, s. 106). Ide o to, čo Bourdieu vo svojej teórii označuje ako druh symbolického násilia.

Druhou stránkou angažovanosti sa sociológov môže byt’ participácia alebo podpora rôznych verejných aktivít zameraných na zmenu existujúcich spoločenských a politických pomerov. Vo Francúzsku sa na konci 20. storočia takouto postavou stal verejný intelektuál a sociológ Pierre Bourdieu, ktorý sa nielen publicisticky, ale aj osobnou účastou zapájal do rôznych protestných podujatí. ${ }^{21}$ Pri porovnávaní programu verejnej angažovanosti (nielen) vedcov Mills naznačil viacero princípov, ktoré môžu slúžit aj na testovanie jeho modelu angažovanosti a súčasných verejných masových akcií, ktoré otriasali verejným a politickým životom na Slovensku a boli prítomné aj v Česku v rokoch 2018 a 2019. Prvým kritériom by mohla byt', pri interpretácií faktov a vysvetlovaní spoločenských javov, ich kontextualizácia, teda využívanie sociologickej imaginácie, ktorá pomáha pochopit históriu a biografiu a ich vzájomný vztah v sociálnej štruktúre spoločnosti. „Sociálny výskum, ktorý sa neustále nevracia k otázkam biografie, histórie a ich pretínaniu v spoločnosti nesplnil svoju intelektuálnu úlohu“ (Mills, 2008, s. 9). Okrem toho, že by mali komentátori aktuálneho politického diania a iniciatív, ale aj výsledkov rôznych výskumov (prostredníctvom chápania ludí, o ktorých hovoria) ich konanie a názory vysvetlovat', mali by zostat’ v prípadných hodnotových a straníckych sporoch nestranní a oslobodení od existujúcich výkladových schém (alebo si aspoň uvedomovat ich relativitu). Pretože sociologická imaginácia je „druhom uvedomenia si vlastného outsiderstva a cudzosti vo svete a schopnostou divit’ sa a žasnút nad svetom“ (Mills, 2008, s.12). No to, čo je dnes prezentované v médiách ako sociologický

${ }^{20}$ Jedným z mnohých príkladov takejto praxe môže byt popis typických charakteristík voliča vytypovanej politickej strany, ktoré majú spojit isté skupiny (kategórie ludí) s negatívne definovaným politickým správaním: https://www.aktuality.sk/clanok/625359/grafy-aky-maju-vek-vzdelanie-a-pracu-volici-smeru/. Rovnaké postupy obsahujú aj články vytvárajúce na základe cielených prieskumov predstavu údivu nad nekonzistentnostou (nerozumnostou) ludí, ktorí prehliadajú nemorálnost: https://dennikn.sk/1085192/odomkli-sme-zavolali-sme-si-volicov-smeru-a-pocuvali-ich-nazor-na-krizu-pre-pokoj-a-stabilitu-prehliadnu-aj-korupciu/ (oba odkazy navštívené 16. 9. 2020).

21 Táto stránka jeho angažovanosti je aj jednou z nosných línií dokumentárneho filmu o Pierrovi Bourdieuovi „Sociológia je bojový šport“ (La Sociologie est un sport de combat) z roku 2001 od režiséra Pierra Carlesa. 
výskum, nie je údiv inšpirujúci k hladaniu vysvetlení. Napríklad v prípade komentovania volebných preferencií politických strán (či podielu nerozhodnutých alebo nevoličov) alebo závažných politických udalostí je niekedy aj explicitne používaný jazyk pobúrenia a morálneho rozhorčenia. Pobúrenia nad konšpiráciami ako vierou v nezmysly, nad nerozumným rozhodovaním sa voličov, nad ochotou volit osoby a strany, ktoré sú v médiách prezentované ako symboly korupcie či extrémizmu, či nad neochotou zúčastňovat sa rôznych typov volieb do zastupitel'ských orgánov.

Pri čítaní zverejňovaných výsledkov výskumov a názorov sociológov sa vynára otázka, komu sú takéto texty určené a čo chcú čitatelom povedat'. Na Slovensku nie sú dominantnou medializovanou témou v súvislosti so sociologickými výskumami štrukturálne problémy spoločnosti, ale to, koho ludia volia a kto sú voliči rôznych strán. Analýzy volebných preferencií či vyhodnocovanie rôznych tém z výskumov na základe politického alebo straníckeho profilu respondentov je pravdepodobne najčastejšou témou, cez ktorú verejnost na Slovensku vníma sociológiu. ${ }^{22}$ Voliči ktorých strán viac tolerujú korupciu, či vo väčšej miere veria konšpiráciám, voliči ktorých strán podporujú radikálne zvyšovanie platov v školstve a podobne sú len drobnými príkladmi spájania istých presvedčení s prijatel'nou alebo neprijatelnou politickou orientáciou. Alebo, naopak, ide o spájanie morálne odsudzovaných prejavov s istými skupinami či priamo politickými stranami.

Na rozdiel od dobových Millsových záverov, že vedci v rôznych spoločenských vedách sú súčastou aktuálneho politického poriadku a jeho legitimizátormi, v súčasnosti na Slovensku a aj v strednej Európe vidiet tendencie, ktoré sú zdanlivo v rozpore s Millsovými charakteristikami modernej vedy. Velká čast médií na Slovensku (na rozdiel od Česka či Madarska, kde sa vládna politická moc rôznymi spôsobmi prepojila aj so súkromnými médiami) vystupuje velmi kriticky proti existujúcej vláde ${ }^{23}$ a táto kritickost je aj súčastou interpretácií, s ktorými do médií vstupujú mnohí sociálni vedci. Napriek tomu v tomto prípade kritického postoja voči moci nejde o ten typ verejného informovania a vzdelávania, aký propagoval Mills. Na Slovensku je mediálny svet druhom opozície voči aktuálnej politickej moci, no nie voči aktuálnemu mocenskému usporiadaniu spoločnosti s jej mocenskou elitou a štrukturálnymi problémami. Zdanlivost podobnosti s millsovskými analýzami vyplýva z odlišných kontextov - historických aj globálnopolitických. Slovensko, podobne ako aj iné stredoeurópske štáty je súčastou rôznych nad- a transnárodných zoskupení a je vystavené pôsobeniu ekonomických korporácií, ktorých reprezentácie sa stávajú súčastou elít aj národných štátov, a to predovšetkým svojím mocenským vplyvom a možnostami spoluformovat podmienky a pravidlá života v nich. Aktuálne konštelácie vládnych elít $\mathrm{v}$ národných štátoch sú však často $\mathrm{v}$ konflikte $\mathrm{s}$ týmito transnárodnými elitami. Formovanie sociálnej, daňovej a hospodárskej politiky, zákonníkov práce a dalšie princípy formovania pravidiel života spoločnosti sú predmetom boja rôznych skupín o ich podobu. A práve v médiách je tento boj často najviditel’nejší, no nie explicitne vyjadrený a médiá sú aj účastníkmi sporov na niektorej z bojujúcich strán.

22 Táto tendencia je dlhodobo súčastou aj akademickej sociológie, kde sa analýza politických preferencií vo vztahu k iným druhom správania a postojov stáva dôležitou a pravdepodobne najčastejšie robenou analytickou témou.

23 Ide o vládnu zostavu fungujúcu do februára 2020, ked’ došlo po asi 12 rokoch k pravdepodobne už nie len krátkodobému odchodu stále najsilnejšej strany SMER do opozície a k vypadnutiu jej koaličných partnerov z parlamentnej politiky. 
Velmi vhodným analytickým materiálom o tom, v čí prospech môžu byt’ sociologické analýzy robené (alebo v čí prospech sú možno aj nestranne zozbierané a vytvorené výsledky v médiách prezentované) môže byt článok o zmenách voličskej základne vládnej strany SMER „Ficovi ušli takmer všetci mladí, bez dôchodcov by Smer nemal ani desat’ percent“. ${ }^{24}$ Jazyk samotného článku príslovečne vytvára obraz pozitívneho sveta mladých, vzdelaných a podnikavých ludí, stojaceho v kontraste so svetom dôchodcov, svetom odchádzajúcej minulosti a zániku. Svojím diskurzívnym rámcovaním zapadá do série politickej reklamy, aká existuje napríklad aj v Českej republike, kde sa jej modelovým príkladom už dávnejšie stalo predvolebné mobilizačné video „Přemluv bábu!"25 Zatial' čo na Slovensku žurnalistické interpretácie rôznych spoločenskovedných analýz explicitne nespochybňujú lavicovost’ v takej miere, ako je tomu v prípade známeho českého videa, a zvyčajne nie sú otvorene súčastou predvolebných kampaní, napriek tomu používajú rovnaké stratégie stigmatizácie tých, ktorí stoja na (pre nich) nevhodnej strane politického zápasu. Problematizuje a rôznymi sémantickými stratégiami dehumanizuje starších ludí, ludí s nižším vzdelaním a ludí z vidieka. Tieto sociodemografické charakteristiky sú nielen $\mathrm{v}$ tejto kampani spájané s takými negatívnymi hodnoteniami, ako napríklad nezodpovednost’ voči budúcnosti alebo že si ju „prejeme“, spojenie s minulým režimom, selektívna pamät, zadlžovanie a podobne. Hoci text a video sú súčastou politického boja strán o moc, nehovoria o tom a ani nepriznávajú, v prospech ktorej z bojujúcich strán (nemusí to byt’ v zmysle konkrétnej politickej strany) bojujú. Pre sociológiu sa to stáva obzvlášt problematické, ak ide o formát novinovej analýzy, ktorá svoje hodnotové stanoviská spája s grafmi a číselnými prepočtami, čo vytvára dojem vedeckosti, neutrality a objektivity. V tomto prípade sa ukazuje v podstate to isté, k čomu došiel Mills, teda že ekonómia pravdy vyhráva nad politikou pravdy. Za dôležitú súčast’ výskumnej činnosti považuje „ekonómiu pravdy“, teda náklady spojené s výskumom a toto je podla neho v rozpore s politikou pravdy, teda s užitočnostou výskumu pre objasňovanie významných problémov a pre približovanie politických sporov realite (Mills, 2008, s. 73).

\section{Sociológia a médiá}

Súčasná podoba vzájomného vztahu sociológie a médií na Slovensku sa v istých ohladoch podobá situácii, akú popisoval Mills, v iných sa už výrazne odlišuje. Otázkou je, či by malo dnes zmysel vkladat nádeje do žurnalistov ako tých, ktorí môžu pomáhat pri rozvíjaní sociologickej imaginácie verejnosti. Nie ani tak kvôli tomu, že by sa novinári nejako morálne profesionálne zhoršili, ale preto, že sa zmenili ich možnosti na nezávislý výkon práce a ich možnosti spoluvytvárat podmienky svojej práce. Na riziká súčasného vztahu sociológie a médií (najmä televízie) kriticky poukázal napríklad Bourdieu (2001, 2002). Na príklade televízie ukazuje rôzne formy neviditelnej cenzúry, ktorá súvisí so stratou autonómie pozvaného intelektuála (sociológa), ale aj samotného novinára, ktorá je okrem iného spojená s faktom, že je im vnútená téma aj podmienky komunikácie. Druhým rizikom médií, najmä vizuálnych, napríklad televízi je fakt, že obraz môže vyvo-

24 https://dennikn.sk/1449806/ficovi-usli-takmer-vsetci-mladi-bez-dochodcov-by-smer-nemal-ani-desat-percent/ (navštívené 20. 2. 2020).

25 Dostupné na https://www.youtube.com/watch?v=MLfFhdcXJhA (navštívené 20. 2. 2020). 
lat istý druh dojmu skutočnosti, teda môže ukázat’ a presvedčit’ o tom, čo ukazuje. A táto evokačná sila má mobilizačné účinky, lebo môže umožnit vznik myšlienok alebo predstáv nielen u jednotlivca, ale aj u skupín ludí. Sociálne vytvorená skutočnost̉ však dokáže vyvolávat sociálne efekty mobilizácie alebo demobilizácie (Bourdieu, 2001). Napriek tomu, že sociológia v médiách ako v samostatnom poli stráca čast’ svojej aj tak malej autonómie, jej prítomnost' v nich na Slovensku, rovnako ako aj v iných stredoeurópskych krajinách je stále viditelnejšia. Tento zdanlivý paradox však ukazuje na zmenu významu sociológie v médiách, no zároveň aj na zmenu obrazu sociológie vo verejnosti na základe toho, ako je táto disciplína prezentovaná. Bourdieu hovorí v prípade novinárstva, a to nielen televízneho, o kolaborácii alebo o logike trójskeho koňa. $\mathrm{V}$ takom prípade ide o to, že do nezávislých svetov prepašujeme heteronómnych aktérov, ktorí s podporou vonkajších síl získajú posvätenie, ktoré nemôžu získat’ od seberovných. Vytvárajú sa takto spisovatelia pre nespisovatelov, filozofi pre nefilozofov, ktorí budú mat televíznu reláciu, teda novinársky vplyv bez spoločného porovnania s ich špecifickým vplyvom, vich špecifickom prostredí (Bourdieu, 2002). V prípade Slovenska je vidiet', že v médiách sú najčastejšie označovaní za sociológov tí, čo sú riaditelmi alebo vlastníkmi agentúr pre výskum verejnej mienky, z ktorých sú síce viacerí aj vzdelaním sociológovia, no bez väčšieho (v prípade mnohých z nich akéhokolvek) profesionálneho uznania (či už v podobe pozývania do debát, citovania alebo tematickej expertnosti) v rámci akademického spoločenstva. Pozícia mediálneho sociológa (politológa a podobne) však nemusí byt’ spojená len so sférou výskumov verejnej mienky, existuje aj úzky okruh takzvaných omnibusových (mnohotematických) sociológov. Tí sú ochotní vyjadrit’ sa takmer k akejkolvek téme spôsobom, aký oceňujú novinári, ktorí takýchto mediálnych sociológov vyhladávajú a oslovujú. Nie je náhoda, že v médiách sociológia nie je prezentovaná verejnosti ako veda, ale ako prieskumy verejnej mienky, prípadne ako komentáre sociológov k témam, ktoré si sami nevybrali.

Tretou podobou prítomnosti sociológie v médiách je, ak sa sociológovia verejne angažujú v politike alebo mimovládnom sektore, teda sú verejne aktívni. ${ }^{26}$ Mnohí sociológovia sú aj takýmto spôsobom prítomní v médiách pri legitimizácii nejakého politického diskurzu, politického názoru či straníckych kandidátov. K tomu aj spôsob prezentácie výsledkov práce sociológov, ako aj ich vystúpenia zvyčajne vytvárajú vo verejnosti nejaký obraz sociológie, ktorý nie je vždy v súlade s obrazom, aký by radi vytvárali sociológovia. No na druhej strane velakrát aj sociológovia aktívne prispievajú k obrazu, aký je o sociológii vytváraný napríklad tým, aký typ informácií a záverov výskumov mediálne ponúkajú na prezentáciu. Často je takýto obraz výsledkom dominantnejšej pozície novinárov, ktorí môžu obraz sociológie vytvárat skôr podla svojich záujmov a potrieb v porovnaní so záujmami sociológov. Inokedy ide o pomerme vyrovnanú spoluprácu, ked' sa základné definície situácie a hodnotové schémy novinárov i sociológov výrazne prelínajú a môžu v rámci toho, čo Bourdieu označuje ako spoločný habitus, vytvárat dojem porozumenia a zhody.

${ }^{26}$ V prípade viacerých kandidátov na poslancov parlamentu sa uvádzala ako ich profesia sociológ. Rovnako bývajú ako sociológovia prezentovaní mnohí politici aj počas výkonu politických funkcií, akoby pokračovali vo svojej sociologickej práci. Ukážkovým príkladom takejto sociologickej expertnosti v politike bolo pôsobenie sociologičky Ivety Radičovej vo viacerých politických funkciách, no najmä počas kandidatúry na prezidentku SR a v pozícii premiérky vlády Slovenskej republiky. 
V médiách sa vyskytuje niekol'ko základných spôsobov prezentácie výsledkov sociologického bádania, ktoré by sa dali rozdelit do piatich okruhov a ktoré spoločne vytvárajú obraz sociológie vo verejnosti a zároveň slúžia na formovanie verejnej mienky. Spoločne vyjadrujú niekol'ko už skôr spomenutých princípov, na základe ktorých liberálna účelnost’ dokáže definovat’ „problém“ hodný skúmania, napríklad určovanie toho, čo sa odchyluje od zásad normality, čo nie je v súlade s pokrokárskymi víziami prekonávania kultúrneho zaostávania alebo neschopnosti sa prispôsobit kultúrnemu pokroku.

\section{a) Rebrícky}

Velmi časté sú v médiách pri interpretácii výskumov verejnej mienky alebo výsledkov iných komparatívnych spoločenskovedných výskumov využívané grafy či rebríčky usporiadavajúce porovnávané entity, napríklad krajiny. Zvyčajne býva toto usporiadanie aj komentované spôsobom, ktorý naznačuje (a potvrdzuje grafickým znázornením) hierarchiu (zvyčajne aj hodnotovo definovaného) usporiadania (úroveň úspechu žiakov, index štastia, miera modernizácie, úroveň rozvoja) entít alebo skúmaných javov. V prípade porovnávania krajín EÚ sú výsledky usporiadané aj s naznačením priemeru EÚ a grafickým znázornením krajín pod a nad týmto priemerom. Velká čast’ porovnávaní vytvára takto obraz normality, normativity a želatelnosti, teda druh ideálu, kam by sme mali smerovat' a patrit'. Sme ako krajina tolerantnejšia ako iné (aspoň ako priemer)? Sme modernejší? Podobáme sa viac na krajiny, ktoré sú nám takto predkladané ako pozitívny vzor (Nemecko, USA, Vel'ká Británia) alebo sme medzi krajinami, ktoré symbolizujú úpadok, zaostalost', korupciu, nedemokraciu (Rusko, Bulharsko, Bielorusko)? Tieto texty nebývajú postavené na historickej reflexii a kontextualizácii vývoja, cielom nie je pochopenie ich súčasnej situácie, prípadne vysvetlenie príčin súčasného stavu (teda vedecké otázky), ale zvyčajne ide o normatívny a modernizačný impulz byt súčastou „skupiny krajín“ západnej civilizácie. Teda ide o diskurz konformizácie s prezentovaným vzorom, čo sa dá označit' aj ako ideologické pôsobenie médií.

\section{b) Predvolebné prieskumy preferencií politických strán}

Ide o najčastejšie prítomné zobrazovanie výskumov v médiách. Podobne ako pri mnohých iných politicky zameraných výskumoch, aj v predvolebných prieskumoch politických preferencií sa deskripcia výsledkov výskumov v médiách zvyčajne robí ako triedenie podla niektorých základných dichotómií alebo hodnotovo definovaných kategórií (mladí/starí, ludia s vyšším/nižším vzdelaním, vidiecka/mestská populácia, stredné triedy/nižšie triedy, voliči vládnych/opozičných strán). Tieto dichotómie spájajú niektoré názory, preferencie alebo typy správaní s pozitívne charakterizovanými aktérmi (špecifickými politickými stranami, názormi alebo typmi správania), iné zasa s negatívne prezentovanými javmi a skupinami (voliči istých strán, konšpirátori, konzervatívci, tolerujúci korupciu). Prostredníctvom hodnotovo, esteticky či morálne charakterizovaných voličov bývajú hodnotovo zarámcované strany, ktoré rôzne hodnotené skupiny volia. Samostatným spôsobom vstupu sociológov do volebných kampaní býva (či už pri práci s výsledkami prieskumov preferencií alebo aj bez nich) zapojenie sa do kampaní za racionálne rozhodovanie sa voličov vo volbách, prípadne do mobilizácie nevoličov k volebnej aktivite. Kampane usmerňujúce voličov k racionalite (aby sa nestratil hlas volbou nezvolitelnej strany) ukazujú práve prostredníctvom prieskumov, ktoré strany nie sú márnou investíciou volebného hlasu. 
A tým, samozrejme, aj ovplyvňujú volebné preferencie v prospech silnejších politických aktérov a to bez toho, aby museli otvorene propagovat volbu väčších strán. Kampane za racionálny výber slúžia najmä v prospech velkých politických strán.

\section{c) Vymyslené výsledky výskumov alebo výskumy na objednávku vyrobené tak, aby výsledky podporovali záujmy objednávatela}

Už dlhodobo sa pred každými volbami objavia rôzne novovytvorené agentúry, ktoré prinášajú prieskumy straníckych preferencií alebo podobné merania, ktoré bývajú volne zamieňané za volebné preferencie (volebné modely, merania volebných potenciálov). ${ }^{27}$ Sú prípady, ked' ide o úplne vymyslené výsledky. ${ }^{28}$ Častou (najmä v posledných rokoch) mediálnou stratégiou však je vytváranie obrazu zvolitelnosti strany do parlamentu (na Slovensku $5 \%$ ) tým, že sú pre tento ciel zvolené neštandardné metodologické nástroje alebo je odlišne položená otázka, ktorá podporuje tendenciu k istým typom odpovedí. Metodologicky nekorektné otázky sa stávajú súčastou aj iných ako predvolebných prieskumov. ${ }^{29}$

\section{d) Interpretácie „ohrozeni“ vo výsledkoch výskumov verejnej mienky}

Ďalším príkladom mediálnych prezentácií výsledkov prieskumov, napríklad aj predvolebných, sú odlišné hodnotenia rôznych strán politického boja alebo trendov vývoja s naznačením, čo je hrozbou (pre demokraciu, modernizáciu alebo pokrok) a čo, naopak, nádejou. Príkladom môžu byt’ prezidentské volby na Slovensku v roku 2019, kde po prvom kole postúpili do druhého dvaja z dvanástich kandidátov. Analytici v televíznych debatách, ale i v novinách sa zhodli na tom, že obaja kandidáti potrebujú pre svoje vítazstvo mobilizovat aj dalších voličov okrem tých, ktorí ich volili v prvom kole. V prípade

27 Príkladom prezentácie takýchto výsledkov môže byt spôsob, ako sa mediálne prezentovala ako zvolitelná strana bývalého slovenského prezidenta Andreja Kisku. V jednom článku sú kombinované výsledky volebných preferencií a výsledky volebného modelu, ktorý meral volebný potenciál. Podla iných a neskorších prieskumov už strana A. Kisku nemala volebné preferencie na takej úrovni, ako ukazoval niekolko mesiacov skôr robený volebný model, no strana začala byṫ zarad’ovaná do prieskumov ako relevantná a zvolitelná strana. Tak sa stala súčastou rôznych modelov a kombinácií na možné koaličné vztahy s inými stranami, ktoré v prieskumoch prekračujú dôležitú $5 \%$ hranicu pre možný vstup do parlamentu; https://dennikn.sk/1492731/kiskov-rychly-start-je-prvym-meranim-strany -bez-nazvu-a-ludi-zacal-vsak-dobre/ (navštívené 16. 9. 2020).

28 Známy je prípad strany ANO (Aliancia nového občana) Pavla Ruska, ktorá sa stala „volitelnou“, teda prekročila hranicu $5 \%$ volebných preferencií len na základe vyjadrenia P. Ruska, že to vychádza z výskumu. Takýto výskum nebol nikdy potvrdený, no neskôr už prieskumy dávali strane preferencie okolo $5 \%$ a strana sa nakoniec v roku 2002 do parlamentu dostala s výsledkom viac ako 8 \% získaných hlasov.

${ }^{29}$ Jedným z takýchto príkladov môže byt aj prieskum názorov na interrupciu, ktorý si objednala iniciatíva spojená s pro-life organizáciami organizujúcimi masové pochody za sprísnenie legislatívy umožňujúcej potrat. Výskum prebehol práve v čase takéhoto pochodu a výsledky boli použité počas debaty v parlamente o návrhoch na sprísnenie alebo úplné zakázanie možnosti interrupcií. Namiesto štandardného spôsobu zistovania názorov na interrupcie bola otázka doplnená sugestívnou formuláciou „ked’ dietatu bije srdce“. Výsledky boli pri takto položenej otázke ovela vy̌šsie $\mathrm{v}$ prospech negatívneho postoja $\mathrm{k}$ takto definovanej možnosti ako $\mathrm{v}$ iných výskumoch s neutrálne položenou otázkou. Výsledky prieskumu boli medializované bez akéhokolvek metodologického komentára alebo kritiky sociológov, iba sa odkazom na názov renomovanej agentúry a stali sa súčastou politického zápasu o podobu legislatívy: https://spravy.pravda.sk/domace/clanok /527007-focus-dve-tretiny-slovakov-nepovazuju-pravo-zeny-na-potrat-dietata-ktoremu-uz-bije -srdce-za-spravne/ (navštívené 16. 9. 2020). 
kandidáta č. 1 uvádzali v médiách, že ten bude hladat taký jazyk, aby oslovil aj voličov iných kandidátov z prvého kola, vrátane voličov extrémistických kandidátov. Kandidát bol analytikmi a novinármi spájaný so zmenou a nádejou. Šlo o kandidáta mestských a vzdelanejších voličov, pozitívne vykreslovaného v médiách. V prípade kandidáta č. 2 komentovali jeho budúce kroky tak, že bude mobilizovat zvoleným jazykom extrémistických kandidátov a bude u nich hladat podporu. Teda posunie sa viac k extrémizmu. S týmto kandidátom spájali slová ako riziko, marazmus. Pri ňom sa vytvoril neprítažlivý obraz jeho typického voliča (z vidieka, nevzdelaného a podporujúceho vládnucu stranu a vládu). Nielen novinári, ale aj experti prezentovaní pod hlavičkou akademických pracovísk vstupovali do debaty s hodnotovo vyhranenými hodnoteniami oboch kandidátov. V debatách a novinách boli prezentovaní a aj sa sami prezentovali ako nestranní komentátori situácie. Počas predvolebného obdobia nevystúpil žiaden $\mathrm{z}$ analytikov napriek svojim hodnotiacim súdom s explicitným priznaním svojich hodnotových a politických preferencií.

Sociológovia, ktorí vystupovali počas predvolebných kampaní alebo pri komentovaní výsledkov volieb, sa zjavne exponovali ako súčast' mocenskej štruktúry a nástroj legitimizácie „režimu pravdy“. Tá nie je vždy súčastou aktuálnej mocenskej politickej konštelácie, ale skôr súčastou širšie chápanej sféry moci, ktorej súčastou sú aj médiá (Bourdieu 2001, 2002).

\section{e) Občiansky aktivizmus}

Pomerne špecifickou oblastou, ktorá nie je explicitne spojená so sociológiou, je sféra občianskeho aktivizmu. Táto oblast’ má pomerne silnú podporu médií a v rámci samotnej sociológie pri jeho rôznych analýzach, rovnako ako v médiách pri vstupe do verejného priestoru je definovaná ako apriórne pozitívny druh pôsobenia občanov vo verejnom priestore. Obraz občianskej angažovanosti či tretieho sektora je zvyčajne prezentovaný ako dichotomický protiklad negatívne hodnotených politických strán. Prezentovaný je ako neideologický, spontánny, nestranný a morálne plnohodnotný. Občiansky aktivizmus so silnou pozitívnou propagáciou v médiách a jeho legitimizáciou aj sociálnymi vedcami sa stal dôležitým politickým aktérom v straníckej politike najmä v rokoch 2017 a 2018. Tento druh aktivizmu propagoval hodnoty angažovanosti a legitimizoval iniciatívy slušných ludí a „občianskej spoločnosti“. V rámci toho sa organizovali diskusie a vzdelávacie podujatia zamerané na rozvíjanie kritického myslenia a debaty (debatné asociácie), v rámci ktorých šlo aj o boj proti dezinformáciám a extrémizmu. Takéto iniciatívy však boli súčastou zápasu o moc v krajine, podobne ako tomu bolo v zmienenom videu $\mathrm{z}$ českej volebnej kampane s výrazne negatívnym posudzovaním jednej skupiny strán a jedného typu politických aktérov zo zdanlivo neutrálnych straníckych (nepolitická politika) a ideologických pozícií, no s implicitne výraznou podporou pravicovej politiky. V prípade týchto aktivít dochádzalo k spojenectvu a spolupráci pri spoločnom definovaní situácie mnohých intelektuálov (komentujúcich politické dianie), novinárov, občianskych aktivistov a politikov (opozičných), v ktorom sa rozplynuli inak vzájomne ovela autonómnejšie (aspoň zdanlivo) sociálne polia.

Všetky tieto príklady prítomnosti sociológie vo verejnom priestore, najmä v médiách ukazujú na výrazne obmedzené možnosti sociológov a sociálnych vedcov na nezávislé formovanie obrazu sociológie a prezentácie sociologických poznatkov či interpretácií vo verejnosti prostredníctvom médií. Pri vytváraní verejného obrazu sociológie zároveň po- 
ukazujú na závislost', a teda podriadenost’ pola sociológie mediálnemu polu. Podobá sa to na situáciu, ktorú Mills v 50. rokoch spájal s neliberálnou (v zmysle neoslobodzujúcou), byrokraticky formovanou sociológiou, slúžiacou ekonomicky a politicky silnejším objednávatel'om, a to aj napriek zdanlivej angažovanosti sociológie. Zdanlivá angažovanost' je zdanlivou dvojakým spôsobom. Na jednej strane vytvára dojem, že je angažovaná tým, že stojí na strane „politiky pravdy“, teda na tej správnej strane sociálnych zápasov. Na druhej strane ide akoby len o zdanlivú angažovanost', kedže sociológia vystupuje z pozície akoby hodnotovo neutrálnej vedy, čo zahmlieva jej silnú hodnotovú zaujatost'.

\section{Hodnotová neutralita vedy}

Čo dnes, v čase ideologického a mocenského využívania sociológie znamená angažovanost' alebo hodnotová neutralita vedy? Prečo Mills kritizuje hodnotovú neutralitu, ak zároveň vidí jej vellkú dôležitost?? Pri rozvíjaní svojich úvah o hodnotovej neutralite vedy a zároveň pri jej verejnej angažovanosti je možné za jeho slovami čítat myšlienky Maxa Webera. Bol to práve Mills, kto do americkej sociológie priniesol aj jeho koncept hodnotovej neutrality vo svojom preklade Weberových štúdií do angličtiny (Bisztray, 1987, s. 40). O to viac je prekvapujúce, že na rozdiel od iných nemeckých autorov Webera pri tejto téme v knihe vôbec neuvádza. Napriek tomu je však u neho Weberova koncepcia neprehliadnutelne prítomná.

Ked' Mills v 50. rokoch kritizoval sociológov za neangažovanost', hoci sa zameriaval najmä na kritiku dobových liberálnych sociológov propagujúcich „hodnotovú neutralitu“ vedy, nevstupoval do polemiky s Weberom, ale so spôsobom, ako je tento koncept v sociológii využívaný a dezinterpretovaný. Sám Mills sa podla vlastných slov snažil, bez ohladu na svoje osobné názory, určit’ význam sociálnych vied a zároveň aj priznával osobný charakter vlastných záujmov, rovnako ako takéto záujmy priznával aj iným, ktorých skúmal (Mills, 2008, s. 26). Vedu staval do centra verejného záujmu práve preto, lebo problém sociálnych vied je verejným problémom a angažovanost’ sa týka práve verejných, nie osobných problémov ludí. Teda tých problémov, ktoré nedokáže vyriešit jednotlivec sám, ale sú štrukturálnym problémom spoločnosti. V súčasnosti ale situácia nie je identická, hoci si môžeme všimnút vela podobností s americkou sociológiou v 50. rokoch. Podobne je dominantné využívanie exaktných údajov ako výsledku sociologických výskumov a spôsob, akým je týmto výskumom pripisovaná objektivita. Rozdielom však je výrazná prítomnost̉ dnešných mediálnych sociológov len na jednej strane politických zápasov.

Dnes je už sociológia vo verejnom priestore výrazne prítomná, a to či už prítomnostou výsledkov sociologických výskumov, alebo verejnými vystúpeniami a intervenciami sociológov, dokonca aj tých vo vrcholovej straníckej politike. Napriek výraznej prítomnosti sociológie vo verejnom priestore, nie je $\mathrm{v}$ ňom prítomná sociologická imaginácia v takom duchu, ako ju do sociologického pojmoslovia zaviedol C. Wright Mills. Rovnako ako vo verejnom priestore aj v samotnej sociológii chýba debata o mieste sociológie ako vedy vo verejnej sfére. ${ }^{30} \mathrm{~V}$ súčasnosti prevláda tendencia odlišná od Millsových predstáv

30 V slovenskej sociológii možno dokonca badat presne opačné tendencie. Príkladom môže byt̉ debata na sociálnej sieti v rámci skupiny zameranej na podporu diskusií a informovanosti o novinkách a stave slovenskej sociológie. $\mathrm{V}$ jednej z debát o kvalite merania volebných preferencií a ich možných 
o tom, že verejnou úlohou sociológie je „objasňovat’ prvky súčasnej stiesnenosti a lahostajnosti“ (Mills, 2008, s. 12) a snaha pochopit tieto javy je nahradená bojom proti nim. Okrem toho sa v podmienkach verejného diskurzu na Slovensku sociológia stala súčastou obhajoby hodnôt a záujmov mestských stredných tried, najmä vysokoškolsky vzdelaných, proti svetu a záujmom iných, najmä horšie sociálne postavených.

Mills nekritizuje hodnotovú neutralitu, ale kritizuje domnelú „hodnotovú neutralitu“ techník výskumu (Mills, 2008, s. 85) dobovej mainstreamovej americkej sociológie. Dôležitost' pri akejkolvek analýze pripisuje, v duchu Webera, schopnosti byt’ si vedomý svojich vlastných hodnôt. „Intelektuál hoden tohto mena sa musí snažit konat’ svoju prácu s vedomím svojich predpokladov a dôsledkov, z ktorých nie najmenšími sú jej morálny a politický význam pre spoločnost', v ktorej pracuje a pre svoju vlastnú úlohu v nej“ (tamže). Rozvíja tu Weberovu ideu o najradikálnejšom pochybovaní ako otcovi poznania (Weber, 1983, s. 174). Práve schopnostou uvedomovat si vlastné hodnotové základy sa neskôr dá aj vysporiadavat s prípadnými konfliktmi, lebo sa dajú pochopit ich zdroje. Predmet konfliktu hodnôt sa prejavuje už aj v predmete skúmania, teda v tom, čo považujeme za problém. Jednou z hlavných úloh sociálnych vied je rozhodnút, či takýto konflikt existuje, alebo nie a ak áno, tak rozlíšit fakty od hodnotenia. Niekedy to vedie $\mathrm{k}$ novej formulácii problému, čo otvára cestu k jeho riešeniu. No hodnotové spory sa nedajú rozriešit ani logicky, ani na základe faktov a v tomto sa ukazuje Mills ako silne ovplyvnený Weberom. Práve ten vo svojej štúdii o hodnotovej neutralite vedy (pričom hovorí najmä o ekonómii a sociológii), popísal vztah medzi hodnotením a praxou. Mills v podstate spolu s Weberom a v jeho duchu kritizuje zdanlivú hodnotovú neutralitu rovnako ako sugestívne narábanie s faktmi. „Práve zdaním, že sa odstránili všetky praktické hodnotenia, možno podla známej schémy: ,nech hovoria fakty' mimoriadne sugestívne vyvolávat tieto hodnotenia“" (Weber, 1983, s. 176). V takomto kontexte je Mills kritický voči deklarovanej hodnotovej neutralite vedy.

$\mathrm{Na}$ „hodnotovú neutralitu“ sa Mills odvoláva ako na nechut prejavit „väčšiu angažovanost $^{\text {“ }} \mathrm{v}$ debatách o „vedeckej objektivite“, ktorá môže byt za istých okolností druhom legitimizácie situácie. „Ospravedlnením mocenského usporiadania a nadvlády mocných menia predstavy a idey moc v autoritu“ (Mills, 2008, s. 89). Kritika hodnotovej neutrality alebo toho, čo je dnes viditel’nejšie - „vášnivej neideologickej angažovanosti“ - sa u Millsa opiera o predpoklad, že je to snaha zneviditelnit alebo popriet fakt, že „každý, kto strávi svoj život štúdiom spoločnosti a publikovaním výsledkov svojej práce, koná morálne a politicky, či si to praje, alebo nie. Ide o to, či túto podmienku prijmeme a vyvodíme z toho dôsledky“ (Mills, 2008, s. 88). Ak prestáva íst’ o konfrontáciu faktov, spory bývajú založené na odlišnosti hodnôt, a to velmi pluralitných, ktoré stoja $\mathrm{v}$ pozadí našich činov. „Medzi hodnotami totiž vždy a všade ide nielen o alternatívy, ale aj o nezmieritelný a smrtelný boj, tak ako medzi ,bohom' a ,diablom. Medzi nimi niet nijakých relativizácií ani kompromisov. Poznamenajme, že čo do zmyslu niet“ (Weber, 1983, s. 185). Aj v tomto Mills tvorivo rozpracováva svoj zdroj inšpirácie. Konflikt hodnôt popisuje takto: „Nová (vynárajúca sa) hodnota nemôže byt realizovaná, ak nie je stará obetovaná, a tak ak chcú

skresleniach pred prezidentskými volbami v roku 2019 sa ako reakcia na kritiku velmi nepravdepodobných výsledkov jedného z výskumov (ktorý ani nemeral preferencie, ale tzv. volebné modely) sa jeden z debatujúcich sociológov voči takejto kritike ohradil slovami: „Predsa nebudeme spochybňovat sociologické výskumy!“ 
zainteresovaní konat', musia íst’ za hodnotou, ktorú si cenia najviac“ (Mills, 1959, s. 77; Mills, 2008, s. 86). „Pri strete hodnôt dvoch strán, ktoré zastávajú protichodné zainteresované osoby, konflikt nemožno riešit logickou analýzou alebo vecným (faktuálnym) skúmaním, a preto sa morálne problémy stanú problémom moci a v krajnom prípade, ak k nemu dôjde, je konečnou formou moci donútenie“ (tamže).

Zatial čo Weber zdôraznil, že hodnotový konflikt je vždy prítomný vo vedeckom bádaní, Mills k tomu pridal mocenskú dimenziu ako schopnost’ presadit konkrétne hodnotové vzory. To viaže otázku hodnôt aj k samotnému empirickému výskumu, ktorý nie je nehodnotiaci len preto, že metóda nie je spojená s hodnotami niektorých skupín. „Normatívne a empirické vedy môžu politicky činným osobám a súperiacim stranám poskytnút iba jednu neocenitel'nú službu, že im totiž povedia: 1 . K tomuto praktickému problému sú myslitel'né tieto a tieto rozdielne „zásadné“ stanoviská, 2. Tak a tak vyzerajú fakty, s ktorými musíte pri volbe medzi týmito stanoviskami rátat“ (Weber, 1983, s. 177). Nedá sa diskutovat' o otázkach vkusu. To sú otázky filozofie hodnôt a nie metodiky empirických disciplín. A práve takáto metodologická nestrannost’ pri prezentácii sociologických výskumov v slovenských médiách absentuje. Práve naopak, sociologické analýzy a interpretácie sú bud’ priamo hodnotovo zatažené, teda sú politické, alebo sú v kontextoch, kde získavajú jednoznačný hodnotový charakter, a teda sú politizované. Vedecké nástroje a interpretácie takto slúžia politickým a nie vedeckým cielom. Ako už bolo naznačené, z kontextu a obsahu hodnotových stanovísk sociológov alebo prezentovaných sociologických výskumov je vidiet', že slovenská angažovaná sociológia sa neposunula k reflexívnej a tým aj oslobodzujúcej sociológii, ale k liberálnej sociológii liberálnych stredných tried z urbánneho prostredia, prípadne dosiahla $\mathrm{v}$ mnohých prípadoch stav byrokratickej neliberálnej zdanlivo hodnotovo neutrálnej podoby zodpovedajúcej Millsom popisovanému abstraktnému empiricizmu.

\section{Záver}

Aj šesṫdesiat rokov od vydania Millsovej Sociologickej imaginácie je táto kniha dôležitou pomôckou, ako hladat' cestu k adekvátnejšiemu pochopeniu našich životov zasadených do štruktúry modernej spoločnosti a ako pracovat so sociologickými výskumami. Je však aj vyargumentovanou pomôckou pri uvedomení si tažkostí sociológov alebo sociálnych vedcov plnohodnotne a aktívne sa podielat na uschopňovaní jednotlivcov a celých skupín vytvárat aktívnu a demokratickú verejnosté Lubomír Sochor v doslove k českému prekladu knihu označil za vyvrcholenie Millsovej sociológie, pretože sama skúma sociológiu a jej funkcie vo vztahoch medzi mocenskou elitou a masou, medzi vládnucimi a ovládanými (Sochor, 1968, s. 204). Kniha nie je učebnicovým úvodom do sociológie, ale úvodom do sveta sebareflexívnej sociológie, ktorá až po vyjasnení si otázky komu slúži môže naplňat svoje definované ambície.

Demokratické podmienky života človeka sú silne spojené aj s demokratickými podmienkami pre sociálne vedy, ktoré zasa spätne umožňujú zlepšovat životné podmienky človeka. V tomto vztahu vedy a ludských záujmov sú neodmyslitelné hodnoty. Jednou z hlavných úloh spoločenských vied, ktorú Mills rozvíja v duchu nemeckej intelektuálnej tradície Maxa Webera, je nutnost' rozlišovat fakty od hodnotenia (Mills, 2008, s. 86). 
Hodnota, ktorú do vedy vedci vkladajú a cenia si ju, však musí byt ako hodnota zjavná, lebo je to spoločne zdielaná hodnota s konkrétnym sociálnym prostredím.

Týmto Mills naznačuje aj jednu $z$ ciest $k$ angažovanosti sociológie. Sám ponúka angažovanost’ ako cestu k človeku. Ak má byt’ sociológia skutočne liberalizujúcou, teda oslobodzujúcou vedou, mala by si nájst’ cestu k človeku, ktorému môže pomôct’ pochopit’ viaceré súvislosti jeho vlastného života. Napríklad tým, že upozornení na prehliadané súvislosti jeho osobného života so sociálnou štruktúrou spoločnosti, zasadenej do kontextu historických zmien a vývoja. V tom sa odlišuje od zdanlivo hodnotovo neutrálnych, objektivizujúcich sociológov, ktorí odpútavaním pozornosti od otázok moci a autority odvádzajú pozornost̉ od štrukturálnych skutočností spoločnosti samotnej. Mills kladie dôraz na hodnotové ukotvenie sociológov bez toho, aby rezignoval na svoju profesionalitu. Kritizuje empiricizmus bez toho, aby znevažoval význam empirického výskumu pre sociológiu. Lebo svojou kritikou dobovej, zdanlivo nehodnotiacej sociológie kritizuje neprofesionalitu v sociológii a nepoctivost’ vo vztahu k základných zdrojom sociológie a jej verejným úlohám. Sochor zhodnocuje Millsovo dielo konštatovaním, že okrem toho, že je silne poznačené jeho individualizmom, obsahuje zároveň aj požiadavku, že sociológ, ktorý chce nadväzovat’ na „klasickú tradíciu“ sociológie, nesmie byt’ len technikom empirického výskumu, ale aj sociálnym myslitel’om a kritikom. Sociologická tradícia zároveň aj určuje poradie hodnôt: prvotné sú idey a problémy, sekundárne sú empirické techniky, ktoré sú podriadené skúmaným problémom, pri formovaní ktorých spolupôsobí práve sociologická tradícia (Sochor, 1968, s. 205).

K dosiahnutiu základných úloh verejnej sociológie je potrebných niekol'ko nevyhnutných podmienok pre samotnú sociológiu. $\mathrm{V}$ prvom rade: nezávislost’ vedca. Tá by sa mala prejavit jeho schopnostou a možnostou pridŕžat' sa jedného z Millsových odporúčaní: „Nedovol', aby oficiálne formulácie verejných problémov alebo súkromné prežívanie osobných t’ažkostí ludí determinovali problémy, ktoré si zvolíš za predmet svojho štúdia. Predovšetkým sa nevzdávaj svojej duchovnej a politickej nezávislosti tým, že by si sa nechal kýmkolvek nútit do neliberálnej účelnosti (praxe) byrokratického étosu alebo liberálnej účelnosti (praxe) morálnych povrchností (Mills, 2008, s. 244). Okrem toho apeluje na úlohu rozumu, ktorý je rolou nezávislého vedca. $\mathrm{V}$ tejto úlohe sa má sociálny vedec snažit konat' demokraticky v spoločnosti, ktorá nie je úplne demokratická. „Konáme však tak, ako keby sme žili v spoločnosti úplne demokratickej, pokúšame sa odstránit to ,ako keby‘. Snažíme sa urobit spoločnost’ demokratickejšou“" (Mills, 2008, s. 205).

Sebauvedomenie si svojich hodnotových východísk je dôležité pre pochopenie ideológie súčasnej doby. Práve to umožňuje nájst’ svoje možnosti na nezávislé a slobodné pestovanie takej podoby vedy, ktorej cielom je aj identifikácia skutočne verejného záujmu, teda záujmu, ktorý nie je obmedzený na konkrétnu čast’ verejnosti na úkor ostatných jej častí. Využívanie sociálnych výskumov totiž nemusí vždy vyplývat zo zámerov sociálnych vedcov samotných. Mnohí vedci si bývavali vedomí politického významu svojej práce, no v dnešnej ideologickej dobe si toho mnohí vedomí nie sú. Tieto riziká zvyšuje závislost’ sociológov pri realizácii takéhoto programu od médií ako spostredkovávatela poznania smerom k širšej verejnosti. Habermas, ktorý sa okrem iného teoreticky venoval fenoménu verejnost', je však podobne ako Bourdieu v súčasných podmienkach voči médiám, obzvlášt voči televíziám vel’mi kritický, rovnako ako je kritický k časti intelektuálov. „Kedže je televízia médium, ktoré niečo zviditelňnje, tým, ktorí verejne vystupujú sprostred- 
kováva prominentnost v zmysle popularity. Pred kamerou aktéri prezentujú sami seba, bez ohladu na to, akým obsahom do programu prispievajú. (...) Moment sebaprezentácie aktérov nevyhnutne mení hodnotiace publikum, ktoré sa pred obrazovkou podiela na hádke o témach verejného záujmu aj na pozorujúce publikum." (Habermas, 2013, s. 14). V tomto ohlade sa musí sociológ alebo ktorýkolvek intelektuál snažit o presadzovanie dialogických a kolegiálnych foriem vztahov s publikom. Dobrá povesṫ intelektuála, ak nejakú má, sa nezakladá v prvom rade na prominentnosti alebo popularite, ale na reputácii, ktorú si musel vydobyt vo vlastnom odbore. Habermas upozorňuje, že ak sa do diskusie zapojí s argumentmi, musí sa obrátit na publikum, ktoré nie je tvorené divákmi, ale potenciálnymi účastníkmi diskusie a jej adresátmi, ktorí sa do diskusie môžu zapojit. V ideálnom prípade ide o výmenu dôvodov, nie o inscenované divadlo. „Intelektuál by vplyv, ktorý získava pomocou slov, nemal používat ako prostriedok na získanie moci, nemal by si teda pliest',vplyv's , mocou“" (Habermas, 2013, s. 14).

Jedným z hlavných odkazov Sociologickej imaginácie je to, na čo už koncom 60. rokov upozornil Lubomír Sochor. Ten zhodnocuje odkaz knihy najmä vo vztahu k sociológii samotnej. Mills podla neho pri analýze úlohy sociológie vo vztahoch medzi elitou moci a ovládanou masou dospieva k záveru, že vtedajšia oficiálna, akademická a aj aplikovaná americká sociológia slúžila k upevneniu monopolného postavenia vládnucej elity dvojjediným spôsobom - na jednej strane ako ideológia a na strane druhej ako nástroj manipulácie más prostredníctvom takzvaného sociálneho inžinierstva. Je to konkrétna analýza americkej sociológie v určitej fáze jej vývoja (Sochor, 1968, s. 213). Pri pokuse využit Sociologickú imagináciu na Slovensku však vidiet, že žiadna takáto kniha ani štúdia, poukazujúca na aktuálny stav slovenskej sociológie a jej miesto v spoločnosti vo vztahu k mocným a ovládaným nie je. Millsova Sociologická imaginácia takto zostáva dôležitým a dostatočne rešpektovaným zdrojom kultivovania sociologickej predstavivosti a sebareflexívnosti.

A aké sú podla Millsa podmienky, ktoré vyžadujeme, aby sme mohli účinne plnit úlohy byt účinnými nositelmi rozumu? Sú $\mathrm{k}$ tomu podla neho nutné politické strany, hnutia a verejnost', ktoré majú tieto rysy: 1 . Sú $\mathrm{v}$ nich otvorene prediskutovávané idey a alternatívy spoločenského života. 2. Majú možnost' skutočne ovplyvňovat rozhodnutia štrukturálneho významu. Iba za existencie takýchto organizácií môžeme realisticky a s nádejou uvažovat o úlohe rozumu $v$ ludských záležitostiach (čo by malo byt̉ predpokladom každej demokratickej spoločnosti). No a v neposlednom rade je základom pluralita. A to nielen pluralita paradigmatická, ktorá je pre mnohých dnes už samozrejmostou, ale aj priznane hodnotová. „Myšlienky sociálnych vedcov by mali vzájomne sútažit a táto sútaž (ako proces aj ako jej výsledky) v ktorejkolvek dobe by mala politickú závažnost" (Mills, 2008, s. 206).

\section{LITERATÚRA}

Alijevová, D. (1985). Súčasná americká sociológia. Bratislava: Nakladatel’stvo Pravda.

Balon, J. (2002). Jak se odstřelují posvátné krávy. Literární noviny 31, 29. 7. 2002, s. 8.

Balon, J. (2011). Sociologie v USA. Historické kontextualizace. Praha: Sociologické nakladatelství.

Bauman, Z. (1996). Myslet sociologicky. Netradiční uvedení do sociologie. Praha: Sociologické nakladatelství.

Becker, H. S. (1994). Profesionalism in Sociology: The Case of C. Wright Mills. In R. Rist (ed.), The Democratic Imagination: Dialogues on the Work of Irving Louis Horowitz (s. 175-187). New Brunswick: Transaction Books. 
Berger, P. L. (1991). Pozvání do sociologie. Praha: Správa sociálního řízení FMO.

Berger, P. L., \& Berger, B. (1972). Sociology: A Biographical Approach. New York / London: Basic Books.

Bisztray, G. (1987). The Controversy over Value Neutrality in Sociology and Literature. Comparative Literature Studies, 24(1), 40-57.

Bourdieu, P. (1984). Homo Academicus. Paris: Les Éditions de Minuit.

Bourdieu, P. (1989). La noblesse d'État. Grandes écoles et esprit de corps. Paris: Les Éditions de Minuit.

Bourdieu, P. (2001). O televízii (I.). Kino-Ikon, 1-2/2001, 159-165, preložila Zita Ročkárová.

Bourdieu, P. (2002). O televízii (II.). Kino-Ikon, 1/2002, 89-100, preložila Zita Ročkárová.

Bourdieu, P., \& Wacquant, L. J. D. (1992). Invitation to Reflexive Sociology. Chicago: Chicago University Press.

Burawoy, M. (2005). For Public Sociology. American Sociological Review, 70(1), 4-28.

Búzik, B. (2016). Modernizácia a jej vzkriesenie na slovenský spôsob. Bratislava: Sociologický ústav SAV.

Code of Ethics of ISA. The International Sociological Association (ISA). Dostupné on-line na: https:// www.isa-sociology.org/en/about-isa/code-of-ethics/.

Giddens, A. (1999). Sociologie. Praha: Argo.

Habermas, J. (2013). Avantgardistický cit pre relevantnoste. Čím sa vyznačuje intelektuál. In M. Tížik (ed.), Kritická teória Jürgena Habermasa v sociologickom výskume (s. 9-18, preložila Blanka Mongu). Bratislava: Sociologický ústav SAV.

Halsey, A. (2004). A History of Sociology in Britain. Science, Literature and Society. Oxford University Press.

Jeřábek, H. (2014). Slavné sociologické výzkumy (1899-1949). Praha: Sociologické nakladatelství (SLON).

King, A. (2007). The Sociology of Sociology. Philosophy of the Social Sciences, 37(4), 501-524.

Klofáč, J., \& Tlustý, V. (1965). Soudobá sociologie. Praha: Nakladatelství politické literatury.

Kobes, T. (2019). O sociologické imaginaci. Sociální studia/Social Studies, 1/2019, 147-162.

Kubátová, H. (2006). Metodologie sociologie. Olomouc: Univerzita Palackého v Olomouci.

Kusá, Z. (2005). Predstavovanie ctností - príklad prezidentských bilboardov. Sociológia - Slovak Sociological Review, 37(4), 323-350.

Lubelcová, G. (2017). Sociológia sociálnych problémov. Bratislava: STIMUL.

Maffesoli, M. (1993). La Contemplation du monde. Figures du style communautaires. Paris: Grasset.

Mills, C. W. (1959). The Sociological Imagination. New York: Oxford University Press.

Mills, C. W. (2008 [2002]). Sociologická imaginace (2. vydanie). Praha: Sociologické nakladatelství (SLON).

Ritzer, G. (1975). Sociology: A Multiple Paradigm Science. The American Sociologist, 10(3), 156-167.

Sirácky, A. (1971). C. Wright Mills a angažovaná sociológia. Sociologický časopis / Czech Sociological Review, 7(1), 16-24.

Sochor, L. (1968). C. Wright Mills a sociologie sociologie. In C. W. Mills, Sociologická imaginace (s. 193-222). Praha: Mladá fronta.

Sopóci, J., \& Búzik, B. (2019 [1995]). Základy sociológie (6. vydanie). Bratislava: Slovenské pedagogické nakladatel'stvo.

Weber, M. (1983). Zmysel „hodnotovej neutrality“ sociologických a ekonomických vied. In M. Weber, K metodológii sociálnych vied (s. 166-221, preložil Ladislav Kiczko). Bratislava: Pravda. 